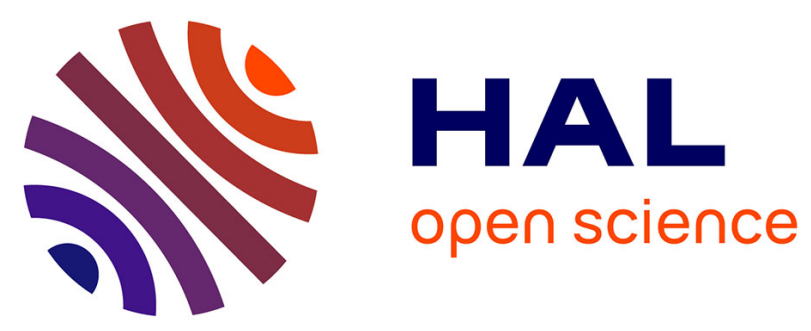

\title{
Cyclic(Alkyl)(Amino)Carbene (CAAC)-Supported Zn Alkyls: Synthesis, Structure and Reactivity in Hydrosilylation Catalysis
}

Jean-charles Bruyere, David Specklin, Christophe Gourlaouen, Rosita Lapenta, Luis Veiros, Alfonso Grassi, Stefano Milione, Laurent Ruhlmann, Corinne Boudon, Samuel Dagorne

\section{To cite this version:}

Jean-charles Bruyere, David Specklin, Christophe Gourlaouen, Rosita Lapenta, Luis Veiros, et al.. Cyclic(Alkyl)(Amino)Carbene (CAAC)-Supported Zn Alkyls: Synthesis, Structure and Reactivity in Hydrosilylation Catalysis. Chemistry - A European Journal, 2019, 25 (34), pp.8061-8069. 10.1002/chem.201900961 . hal-02324087

\section{HAL Id: hal-02324087 https://hal.science/hal-02324087}

Submitted on 4 Feb 2022

HAL is a multi-disciplinary open access archive for the deposit and dissemination of scientific research documents, whether they are published or not. The documents may come from teaching and research institutions in France or abroad, or from public or private research centers.
L'archive ouverte pluridisciplinaire HAL, est destinée au dépôt et à la diffusion de documents scientifiques de niveau recherche, publiés ou non, émanant des établissements d'enseignement et de recherche français ou étrangers, des laboratoires publics ou privés. 


\title{
Cyclic(Alkyl)(Amino)Carbene (CAAC)-supported Zn alkyls: reactivity, structure and use in hydrosilylation catalysis
}

\author{
Jean-Charles Bruyere, ${ }^{[\mathrm{a}]}$ David Specklin, ${ }^{[\mathrm{a}]}$ Christophe Gourlaouen, ${ }^{[\mathrm{a}]}$ Rosita Lapenta, ${ }^{[\mathrm{a}, \mathrm{b}]}$ Luis F. \\ Veiros, ${ }^{[c]}$ Alfonso Grassi, ${ }^{[b]}$ Stefano Milione, ${ }^{[b]}$ Laurent Ruhlmann, ${ }^{[a]}$ Corinne Boudon,,${ }^{[a]}$ and Samuel \\ Dagorne*[a]
}

Dedication ((optional))

\begin{abstract}
The reactivity of $\mathrm{Zn}(\mathrm{II})$ dialkyl species $\mathrm{ZnMe}_{2}$ with a Cyclic(Alkyl)(Amino)Carbene, 1-[2,6-bis(1-methylethyl)phenyl]3,3,5,5-tetramethyl-2-pyrrolidinylidene (CAAC, 1), was studied and extended to the preparation of robust CAAC-supported $\mathrm{Zn}$ (II) Lewis acidic organocations. CAAC adduct of $\mathrm{ZnMe}_{2}$ (2), formed from a 1/1 mixture of $\mathbf{1}$ and $\mathrm{ZnMe}_{2}$, is unstable at room temperature and readily undergoes a CAAC carbene insertion into the $\mathrm{Zn}-\mathrm{Me}$ bond to produce the $\mathrm{ZnX}_{2}$-type species (CAAC-Me) Zn-Me (3), as deduced from NMR data and the solid state structure of 3 . Such a reactivity, arising from the electrophilic character of the CAAC carbene, was further supported by DFT calculations. Insertion product 3 is also unstable at room temperature and decomposes to 1-(2,6diisopropylphenyl)-2,2,4,4-tetramethyl-5-methylenepyrrolidine (4) and 1-(2,6-diisopropylphenyl)-5-ethylidene-2,2,4,4tetramethylpyrrolidine (4') as major organic products, along with $\mathrm{Zn}$ metal, $\mathrm{ZnMe}_{2}$ and $\mathrm{CH}_{4}$. Despite its limited stability, adduct 2 may be cleanly ionized to robust two-coordinate (CAAC) $\mathrm{Zn}-\mathrm{Me}^{+}$cation $\left(5^{+}\right)$ and derived into (CAAC) $\mathrm{Zn}-\mathrm{C}_{6} \mathrm{~F}_{5}{ }^{+}\left(\mathbf{7}^{+}\right)$, both isolated as $\mathrm{B}\left(\mathrm{C}_{6} \mathrm{~F}_{5}\right)_{4}$ salts, reflecting the ability of $C A A C$ for the stabilization of reactive $[\mathrm{Zn}-\mathrm{Me}]^{+}$and $\left[\mathrm{Zn}-\mathrm{C}_{6} \mathrm{~F}_{5}\right]^{+}$moieties. Due to the lability of the CAAC$\mathrm{ZnMe}_{2}$ bond, the formation of bis-CAAC adduct (CAAC) ${ }_{2} \mathrm{Zn}-\mathrm{Me}^{+}$ cation $\left(6^{+}\right)$was also observed and salt $[6]\left[B\left(\mathrm{C}_{6} \mathrm{~F}_{5}\right)_{4}\right]$ was structurally characterized. As estimated from experimental and calculations data, cations $5^{+}$and $7^{+}$are highly Lewis acidic species and the stronger Lewis acid $7^{+}$effectively mediates alkene, alkyne and $\mathrm{CO}_{2}$ hydrosilylation catalysis. All supporting data hints at Lewis-acid-type activation/functionalization processes. Despite a much lower energy LUMO in CAAC derivatives $5^{+}$and $7^{+}$, their observed reactivity was found to be comparable to those of NHC analogues, in line with charge-controlled reactions for carbene-stabilized Zn(II)
\end{abstract}

[a] J.-C. Bruyere, Dr. D. Specklin, Dr. C. Gourlaouen, R. Lapenta, Pr. L. Ruhlmann, Pr. C. Boudon, Dr. S. Dagorne Institut de Chimie (UMR CNRS 7177)

Université de Strasbourg

4 rue Blaise Pascal, 67000 Strasbourg (France)

E-mail: dagorne@unistra.fr

[b] R. Lapenta, Pr. A. Grassi, Dr. S. Milione.

Dipartimento di Chimica eBiologia "Adolfo Zambelli"

Università degli Studi di Salerno

Via Giovanni Paolo II, 84084 Fisciano (SA) (Italy)

[c] Pr. L. F. Veiros

Centro de Química Estrutural, Instituto Superior Técnico

Universidade de Lisboa,

Av. Rovisco Pais No. 1, 1049-001 Lisboa (Portugal)

Supporting information for this article is given via a link at the end of the document. organocations.

\section{Introduction}

Due to their strong $\sigma$-donating properties and steric tunability, $\mathrm{N}$-heterocyclic carbenes (NHCs) are ubiquitous ligands in coordination chemistry for the stabilization of various $\mathrm{metal} /$ heteroatom centers, which has led to significant progress in metal-catalyzed reactions and fundamental organometallic reactivity. ${ }^{[1]}$ In particular, NHC coordination has attracted considerable attention for the stabilization of unprecedented organometallic/inorganic entities both in main group and transition metal chemistry. ${ }^{[2]}$ Though much less studied than classical NHCs, cyclic(Alkyl)(amino)carbenes (CAACs), first reported by Bertrand in 2005, are now emerging as promising carbene ligands that may well complement and even outperform $\mathrm{NHCs}$ due to their specific electronic properties: i.e. an enhanced $\sigma$-donation and a stronger $\pi$-accepting ability $v s$. NHCs. ${ }^{[3]}$ Recent studies on CAAC coordination demonstrated their effective ability to stabilize a number of low-coordinate transition metal species, most notably CAAC-supported $\mathrm{Au}(\mathrm{I})$, $\mathrm{Pd}(\mathrm{II}), \mathrm{Rh}(\mathrm{I})$ and $\mathrm{Ni}(\mathrm{II})$ species. $^{[3,4,5]}$ In main group chemistry, several unusual structural motifs were also recently characterized thanks to the specific electronic properties of CAAC ligands, noticeably including a CAAC-supported formally $\mathrm{B}(\mathrm{I})$ compound, ${ }^{[6]} \mathrm{CAAC}$-stabilized radicals and diradicals, ${ }^{[7]}$ as well as bis(CAAC) adducts of phosphorus arising from the fragmentation of $\mathrm{P}_{4}$ by free CAAC. ${ }^{[8]}$ The activation and functionalization of $\mathrm{E}-\mathrm{H}$ or $\mathrm{E}-\mathrm{E}$ bonds $(\mathrm{E}=\mathrm{B}, \mathrm{Si}, \mathrm{Al}$; primarily in boranes, diboron species and silanes) by CAAC ligands, are also documented and typically lead to the formal insertion of the CAAC carbene atom into the $\mathrm{E}-\mathrm{H}$ or $\mathrm{E}-\mathrm{E}$ bond. ${ }^{\left[{ }^{9]}\right.}$

Besides fundamental reactivity, the use of CAAC-supported metal complexes is also emerging in homogeneous catalysis, thus far essentially with carbophilic metal centers. ${ }^{[5]}$ Most notably, CAAC-Au(I) species were shown to be extremely robust catalysts (even under harsh conditions) for the hydroamination (with $\mathrm{NH}_{3}$ or $\mathrm{NH}_{2}-\mathrm{NH}_{2}$ ) of alkynes and allenes, reflecting the exceptional stability of the CAAC-Au(I) moiety in such catalysts. $^{[5,10]}$ Also noteworthy, the use of a CAAC-supported $\mathrm{Rh}(\mathrm{I})$ catalyst (instead of a NHC analogue) was found to be crucial for high selectivity and activity in aromatic ketones hydrogenation catalysis, illustrating the interest of CAAC-based metal species in catalysis. ${ }^{[11]}$

Due to their attractive features, including a cheap and nontoxic metal source and an enhanced stability thanks to $\mathrm{NHC}$ coordination, NHC-Zn(II) adducts are currently attracting interest, 
in particular for zinc-mediated catalytic processes. ${ }^{[12]}$ This includes the recent development of $\mathrm{Zn}-\mathrm{NHC}$ catalysts in imine hydrogenation, $\mathrm{CO}_{2}$ reductive amination, $\mathrm{CO}_{2}$ hydrosilylation, alkene/alkyne hydrosilylation, allylic alkylation and cyclic esters/carbonates polymerization. ${ }^{[13]} \mathrm{NHC}$ strong $\sigma$-donation also provides enhanced stability to Lewis acidic $\mathrm{Zn}$ (II) organocations, allowing the recent characterization of unprecedented two-coordinate $\mathrm{Zn}(\mathrm{II})$-alkyl cations. ${ }^{[12,14,15]}$ Due to their even stronger $\sigma$ donor character, CAAC ligands stand as potential candidates for additional stability at $\mathrm{Zn}$ (II), an attractive feature for further fundamental developments of organozinc chemistry and related catalytic applications. ${ }^{[16]}$ Yet, contrasting with the recent interest in $\mathrm{NHC}-\mathrm{Zn}$ derivatives, examples of CAAC-supported $\mathrm{Zn}$ (II) species are restricted, to our knowledge, to a report by Roesky, Frenking and Dittrich on the reduction of adduct (CAAC) $\mathrm{ZnCl}_{2}$ to afford either a singlet biradicaloid $\mathrm{Zn}$ (II) species or the $\mathrm{ZnX}_{2}$-type species $(\mathrm{CAAC}-\mathrm{H})_{2} \mathrm{Zn} .{ }^{[17]}$ More generally, the fundamental reactivity and the suitability in catalysis of CAAC complexes of electron-deficient, Lewis acidic and oxophilic metals centers remain to be explored.

We herein report on the reactivity of free CAAC 1 (Scheme 1) with a simple $\mathrm{Zn}$ (II) dialkyl precursor such as $\mathrm{ZnMe}_{2}$ and subsequent derivatization chemistry to access CAAC-supported $\mathrm{Zn}$ (II) organocations. As detailed below, combining CAAC 1 with $\mathrm{ZnMe}_{2}$ may be the source of unexpected reactivity but also afford robust (CAAC) $Z n-R^{+}$and $(C A A C)_{2} Z n-R^{+}$cations, some of which being exploited in hydrosilylation catalysis. The structural features and catalytic performance of such cations are also compared to those of NHC-Zn analogues. ${ }^{[14 b]}$ Experimental data are also supported, whenever possible and appropriate, with DFT calculations.

\section{Results and Discussion}

Reactivity of CAAC 1 with $\mathrm{ZnMe}_{2}$. To access adduct (CAAC)ZnMe 2 (2, Scheme 1), CAAC 1, synthesized according to a literature procedure, ${ }^{[3 \mathrm{a}]}$ was reacted with 1 equiv of $\mathrm{ZnMe}_{2}$ under reaction conditions typically used to prepare $(\mathrm{NHC}) \mathrm{ZnR}_{2}$ ( $R=$ alkyl) species (toluene or pentane, $-35^{\circ} \mathrm{C}$ to $\mathrm{RT}$, overnight). However, such conditions only led to decomposition products, among which CAAC-derived organics 4 and 4' (94\% conv. to a 2/1 4/4' mixture, Scheme 1) and Zn(0) metal (precipitation from the reaction medium) were identified as major products, hence indicating the instability of adduct (CAAC) $\mathrm{ZnMe}_{2}$ (2) at room temperature. The molecular structures of $\mathbf{4}$ and 4' were unambiguously determined through $1 \mathrm{D}$ and $2 \mathrm{D}$ homo-/heteronuclear NMR studies and confirmed by HRMS data (Figures S10-S15, SI). Powder X-ray diffraction data for the metallic residue agree with the formation of $\mathrm{Zn}(0)$ (Figure S16, SI). ${ }^{[18]}$ To gain insight on the reaction between 1 and $\mathrm{ZnMe}_{2}$, low temperature ${ }^{1} \mathrm{H}$ and ${ }^{13} \mathrm{C}$ NMR monitoring studies of a $1 / 1$ $1 / \mathrm{ZnMe}_{2}$ mixture (toluene $\mathrm{d}^{8}$ ) were performed and indicated the immediate and quantitative formation of CAAC adduct 2 at $40{ }^{\circ} \mathrm{C}$ (Figures $\mathrm{S} 1$ and $\left.\mathrm{S} 2, \mathrm{SI}\right)$. In particular, the ${ }^{13} \mathrm{C} \mathrm{NMR}$ spectrum of 2 at $-40{ }^{\circ} \mathrm{C}$ displays a significantly upfield $C_{\text {carbene }}$ signal ( $\delta 267.6 \mathrm{ppm})$ vs. that of free CAAC 1 ( $\delta 304.3$ ppm), consistent with CAAC coordination to $\mathrm{Zn}$ (II). While stable for hours at $-40{ }^{\circ} \mathrm{C}$, adduct 2 quickly rearranges at room temperature to species (CAAC-Me)ZnMe (3, 72\% conversion after $45 \mathrm{~min}$ at $\mathrm{RT}$, Scheme 1; Figure $\mathrm{S} 3, \mathrm{SI}$ ), thus formally resulting from the insertion of CAAC 1 carbene atom into a $\mathrm{Zn}-$ $\mathrm{Me}$ bond of $\mathrm{ZnMe}_{2}$. The identity of species 3 in solution was determined through various $1 \mathrm{D}$ and $2 \mathrm{D}$ NMR experiments (COSY, NOESY, HMBC, HSQC) performed at $-40^{\circ} \mathrm{C}$, all data being consistent with a $C_{1}$-symmetric species, the presence of one $\mathrm{Zn}-\mathrm{Me}$ moiety and a $(\mathrm{Me}) \mathrm{C}-\mathrm{Zn}$ group (Figures $\mathrm{S} 4-\mathrm{S} 9, \mathrm{SI}$ ). Compound $\mathbf{3}$ is also unstable at room temperature and slowly decomposes over the course of several hours to a mixture of products (organics 4 and ' ' in a 2/1 ratio, free $\mathrm{ZnMe}_{2}$ and $\mathrm{CH}_{4}$ ), as deduced from NMR data.

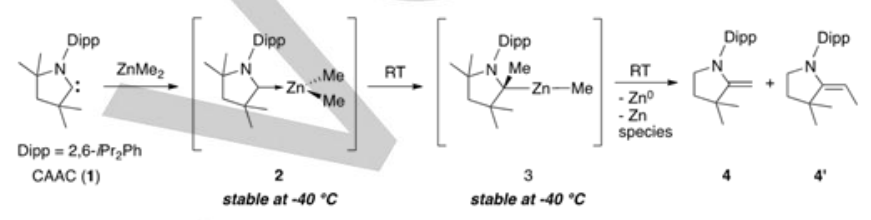

Scheme 1. Reactivity of carbene CAAC 1 with $\mathrm{ZnMe}_{2}$.

Despite the limited stability of CAAC insertion product $\mathbf{3}$, its molecular structure could be unambiguously confirmed through $\mathrm{X}$-ray diffraction studies (crystals grown from saturated pentane solution of a $1 / 11 / \mathrm{ZnMe}_{2}$ mixture at $-40^{\circ} \mathrm{C}$ ). As depicted in Figure 1 , species 3 indeed consists of $Z n X_{2}$-type species with a two-coordinate $s p$-hybridized $Z n(I I)$ center $(\mathrm{C}(1)-Z n(1)-C(22)=$ 176.8(2) ${ }^{\circ}$ ) stabilized by [CAAC-Me] and $\mathrm{Me}^{-}$groups as X-type ligands. The $\mathrm{Zn}-\mathrm{C}_{\text {CAAC-Me }}$ bond distance $(2.017(4) \AA)$ is longer than that of the $\mathrm{Zn}-\mathrm{Me}$ bond $(1.957(6) \AA)$.

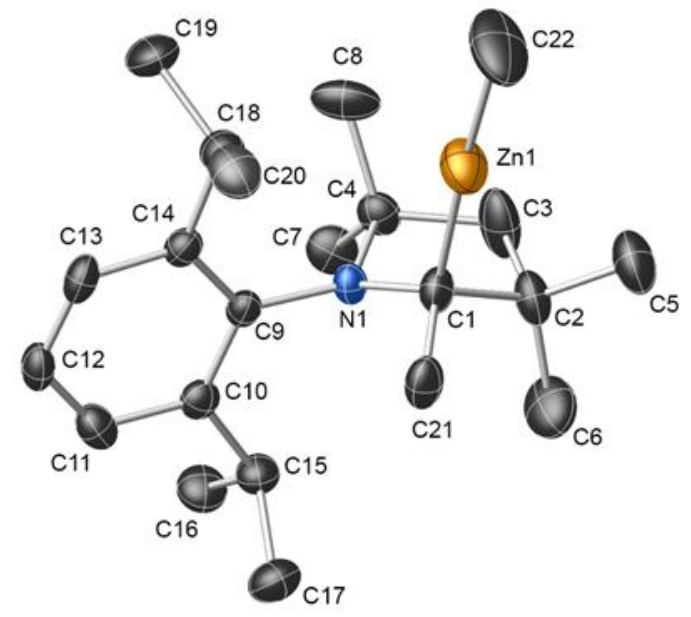

Figure 1. Molecular structure of species (CAAC-Me)Zn-Me (3, ORTEP plot with thermal ellipsoids shown at the $30 \%$ probability level). Hydrogen atoms are omitted for clarity. Selected distances $(\AA)$ and angles $\left({ }^{\circ}\right)$ : $\mathrm{Zn}(1)-\mathrm{C}(1)=$ 2.017(4), $\mathrm{Zn}(1)-\mathrm{C}(22)=1.957(6), \mathrm{C}(1)-\mathrm{N}(1)=1.470(5), \mathrm{C}(1)-\mathrm{C}(21)=1.507(6)$, $C(1)-Z n(1)-C(22)=176.8(2)$ 
To further rationalize the formation of $\mathbf{3}$ from $\mathbf{1}$ and $\mathrm{ZnMe}_{2}$, DFT calculations were performed (B3LYP/6-31+G** level, Figure 2; Figures S35-38, SI). From model CAAC I and $\mathrm{ZnMe}_{2}$, the formation of model adduct II $\left(\triangle \mathrm{G}=-3.8 \mathrm{kcal}^{\mathrm{mol}}{ }^{-1}\right)$ is only slightly exergonic, thus suggesting a rather labile (CAAC) $\mathrm{ZnMe}_{2}$ adduct. Adduct II may then undergo an intramolecular $\mathrm{Me}^{-}$transfer from the $\mathrm{Zn}$ (II) center to the $\mathrm{Zn}-C_{\mathrm{CAAC}}$ atom through transition state TS-II-III $\left(\Delta G=15.8 \mathrm{kcal}^{\mathrm{mol}}{ }^{-1}\right)$ to afford the thermodynamically favored (CAAC-Me)Zn-Me product III $\left(\Delta G=-4.4 \mathrm{kcal}^{\mathrm{mol}}{ }^{-1}\right)$. The formation of III from I and $\mathrm{ZnMe}_{2}$ is thus exergonic and proceeds through a low energy barrier $\left(\Delta \Delta G=19.6 \mathrm{kcal} . \mathrm{mol}^{-1}\right.$ from adduct II), in agreement with experimental observations. From model III and despite several mechanisms probed by DFT, no reasonable pathway accounting for the formation of decomposition products 4, 4', $\mathrm{CH}_{4}$ and $\mathrm{ZnMe}_{2}$ could be computed.

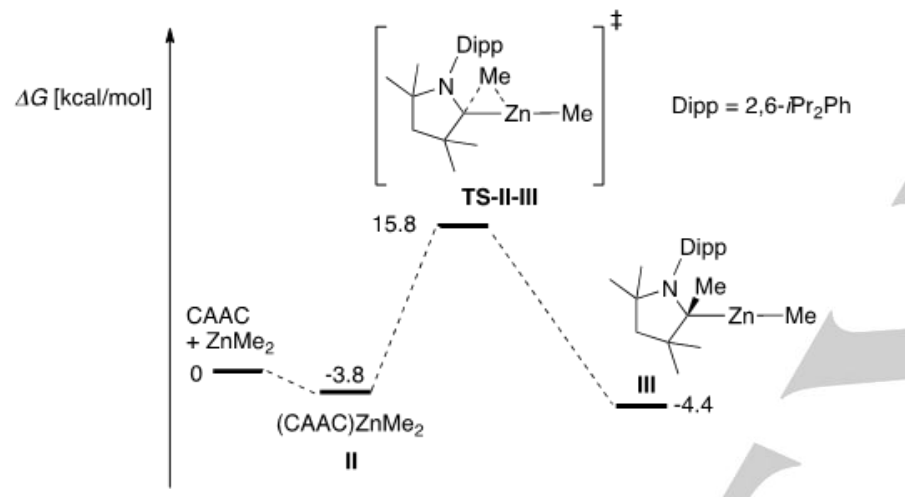

Figure 2. DFT-computed (B3LYP/6-31+G** toluene) reaction profile for the formation of model III from CAAC and $\mathrm{ZnMe}_{2}$.

Overall, the ready formation of insertion product $\mathbf{3}$ from unstable CAAC adduct 2 clearly reflects the enhanced electrophilicity of the CAAC carbene atom and further illustrates the ability of CAACs to activate/functionalize various small molecules through insertion reactivity. ${ }^{[9]}$ Though CAAC insertion in Zn-alkyl bonds is not documented, a related carbene insertion reactivity was recently reported upon combining $\mathrm{ZnR}_{2}$ dialkyls with diamidocarbenes. ${ }^{[19]}$

CAAC-supported $\mathrm{Zn}-\mathrm{R}$ Organocations $5^{+}, 6^{+}$and $7^{+}$as $\mathbf{B}\left(\mathbf{C}_{6} \mathbf{F}_{5}\right)_{4}^{-}$salts. A primary goal of the present study was the synthesis of two-coordinate $\mathrm{Zn}$ (II) cations of the type (CAAC) Zn$\mathrm{R}^{+}$as electrophilic organometallics. Cation (CAAC) $\mathrm{Zn}-\mathrm{Me}^{+}\left(5^{+}\right.$, Scheme 2) may be readily generated by slow addition of adduct 2, generated in situ at $-35{ }^{\circ} \mathrm{C}$, to 1 equiv of $\left[\mathrm{Ph}_{3} \mathrm{C}\right]\left[\mathrm{B}\left(\mathrm{C}_{6} \mathrm{~F}_{5}\right)_{4}\right](-35$ to $\left.0{ }^{\circ} \mathrm{C}, \mathrm{PhF}, 1 \mathrm{~h}\right)$ and was isolated as a $\mathrm{B}\left(\mathrm{C}_{6} \mathrm{~F}_{5}\right)_{4}^{-}$salt $\left([5]\left[B\left(\mathrm{C}_{6} \mathrm{~F}_{5}\right)_{4}\right]\right)$ in good yield $(67 \%)$. In contrast, fast mixing of a $1 / 1\left[\mathrm{Ph}_{3} \mathrm{C}\right]\left[\mathrm{B}\left(\mathrm{C}_{6} \mathrm{~F}_{5}\right)_{4}\right] / 2\left(-35\right.$ to $\left.0{ }^{\circ} \mathrm{C}, \mathrm{PhF}, 1 \mathrm{~h}\right)$ afforded a $1 / 1$ mixture of the bis-CAAC adduct cation $(\mathrm{CAAC})_{2} \mathrm{Zn}-\mathrm{Me}^{+}\left(6^{+}\right.$, Scheme 2) and $\mathrm{ZnMe}_{2}$, as deduced from ${ }^{1} \mathrm{H}$ NMR data. The formation of $6^{+}$arises from a CAAC ligand re-distribution reaction presumably occurring between immediately formed cation $\mathbf{5}^{+}$and unreacted adduct $\mathbf{2}$, and thus indicates the lability of the CAAC- $\mathrm{Zn}$ (II) bond in adduct 2. Such carbene exchange reactions were not observed in $\mathrm{NHC}-\mathrm{Zn}$ chemistry under identical experimental conditions. ${ }^{[14]}$ The identity of salt $[6]\left[B\left(C_{6} F_{5}\right)_{4}\right]$ was confirmed by its independent synthesis by reaction of a $1 / 2\left[\mathrm{Ph}_{3} \mathrm{C}\right]\left[\mathrm{B}\left(\mathrm{C}_{6} \mathrm{~F}_{5}\right)_{4}\right] / 2$ mixture, allowing its isolation in $75 \%$ yield and its molecular structure was established through XRD studies (vide infra).

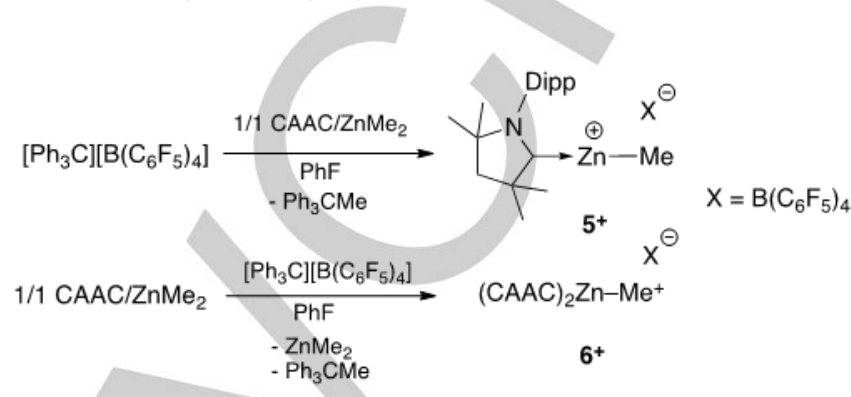

Scheme 2. Synthesis of CAAC-supported $\mathrm{Zn}$ organocations $5^{+}$and $6^{+}$as $\mathrm{B}\left(\mathrm{C}_{6} \mathrm{~F}_{5}\right)_{4}$ - salts.

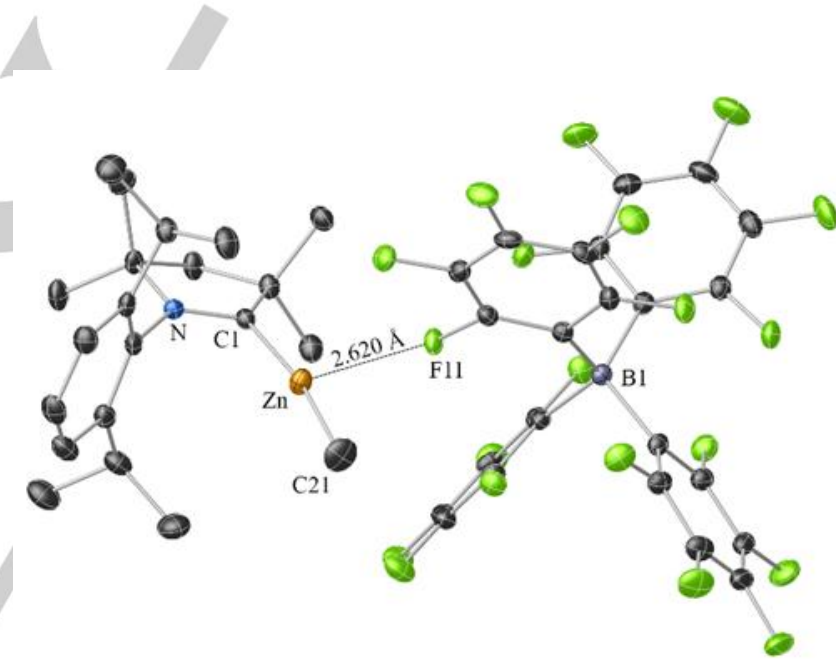

Figure 3. Molecular structure of $[(\mathrm{CAAC}) \mathrm{Zn}-\mathrm{Me}]\left[\mathrm{B}\left(\mathrm{C}_{6} \mathrm{~F}_{5}\right)_{4}\right] \quad\left([5]\left[\mathrm{B}\left(\mathrm{C}_{6} \mathrm{~F}_{5}\right)_{4}\right]\right)$ ORTEP plot with thermal ellipsoids shown at the $30 \%$ probability level). Hydrogen atoms are omitted and selected atoms are labelled for clarity Selected distances $(\AA)$ and angles $\left({ }^{\circ}\right)$ : $\mathrm{Zn}-\mathrm{C}(1)=1.976(3), \mathrm{Zn}-\mathrm{C}(21)=$ 1.913(4), $Z n \cdots F(11)=2.620(3), C(1)-Z n-C(21)=170.2(2)$.

Unlike its parent compound 2, CAAC-supported $\mathrm{Zn}-\mathrm{Me}^{+} \mathbf{5}^{+}$is thermally stable at ambient temperature whether in the solid state or in solution. At room temperature, it is stable for days in $\mathrm{C}_{6} \mathrm{D}_{5} \mathrm{Br}$ but decomposes within minutes in $\mathrm{CD}_{2} \mathrm{Cl}_{2}$ to unknown species. NMR data for $[5]\left[B\left(C_{6} F_{5}\right)_{4}\right]\left(C_{6} D_{5} B r, R T\right)$ agree with the proposed formulation, with, in particular, a ${ }^{13} \mathrm{C}$ NMR $C_{\text {carbene }}$ signal for $5^{+}$significantly upfield shifted $v s$. that of the neutral precursor 2 ( $\delta 231.7$ and 267.6 ppm, respectively), which is in line with a more Lewis acidic $\mathrm{Zn}(\mathrm{II})$ in $5^{+} .{ }^{[20]}$ As determined through $\mathrm{X}$-ray diffraction studies, salt $[5]\left[\mathrm{B}\left(\mathrm{C}_{6} \mathrm{~F}_{5}\right)_{4}\right]$ crystallizes as discrete $5^{+}$and $\mathrm{B}\left(\mathrm{C}_{6} \mathrm{~F}_{5}\right)_{4}^{-}$ions in close contact (Figure 3 ) with a rather short $\mathrm{Zn}(1) \cdots \mathrm{F}(11)$ distance $(2.620 \AA$, i.e. $0.2 \AA$ shorter 
than the sum of the van der Waals radii for $\mathrm{Zn}$ and F). Cation $\mathbf{5}^{+}$ incorporates a central two-coordinate $s p$-hydridized $\mathrm{Zn}$ (II) center with $\mathrm{Zn}-\mathrm{C}_{\mathrm{CAAC}}$ and $\mathrm{Zn}-\mathrm{Me}^{+}$bond distances (1.976(3) and $1.913(4) \AA$, respectively) similar to those in (IDipp) $Z n-M^{+}$ $(1.943(2) \AA$ and $1.895(1) \AA)$, in line with an enhanced electrophicity at $\mathrm{Zn}(\mathrm{II})$.

Unlike $[5]\left[B\left(\mathrm{C}_{6} \mathrm{~F}_{5}\right)_{4}\right]$, the solid state structure of the bis-CAAC adduct species $[6]\left[\mathrm{B}\left(\mathrm{C}_{6} \mathrm{~F}_{5}\right)_{4}\right]$ (Figure 4) consists of fully dissociated ions with no $5^{+} / \mathrm{B}\left(\mathrm{C}_{6} \mathrm{~F}_{5}\right)_{4}{ }^{-}$close contacts, reflecting an greater steric hindrance at $\mathrm{Zn}(\mathrm{II})$ due to an additional CAAC ligand and a less electrophilic $\mathrm{Zn}(\mathrm{II})$ center. Cation $6^{+}$is a threecoordinate $\mathrm{Zn}(\mathrm{II})$ center with a distorted trigonal geometry $\left(\mathrm{C}(21)-\mathrm{Zn}(1)-\mathrm{C}(1)=125.03(1)^{\circ}\right)$. The $\mathrm{Zn}-\mathrm{C}_{\text {CAAC }}$ bond distances in $\mathbf{6}^{+}[2.052(3)$ and $2.045(3) \AA]$ are significantly longer than in $\mathbf{5}^{+}$ (1.976(3) Å)

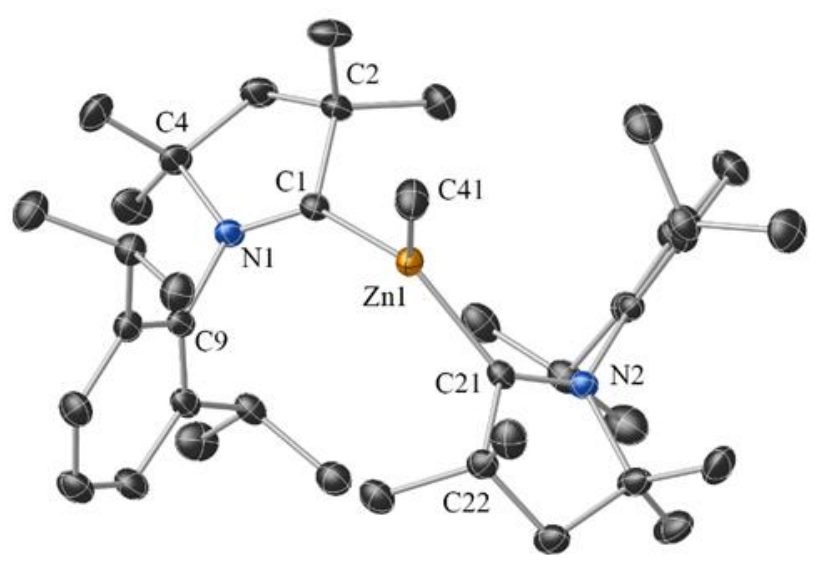

Figure 4. Molecular structure of cation $\left[(\mathrm{CAAC})_{2} \mathrm{Zn}-\mathrm{Me}\right]^{+}\left(6^{+}\right.$, ORTEP plot with thermal ellipsoids shown at the $30 \%$ probability level). Hydrogen atoms are omitted and selected atoms are labelled for clarity. Selected distances $(\AA)$ and angles $\left({ }^{\circ}\right)$ : $\mathrm{Zn}(1)-\mathrm{C}(1)=2.052(3), \mathrm{Zn}(1)-\mathrm{C}(21)=2.045(3) \AA, \mathrm{Zn}(1)-\mathrm{C}(41)=$ $2.003(3), C(1)-Z n-C(21)=125.0(1)$.

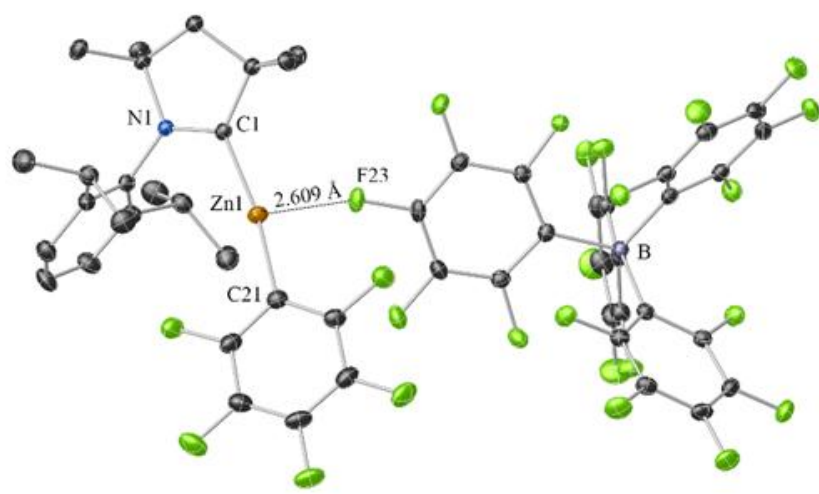

Figure 5. Molecular structure of ion pair $\left[(C A A C) Z n-C_{6} F_{5}\right]\left[B\left(C_{6} F_{5}\right)_{4}\right]$ $\left([7]\left[B\left(C_{6} F_{5}\right)_{4}\right]\right.$, ORTEP plot with thermal ellipsoids shown at the $30 \%$ probability level). Hydrogen atoms are omitted and selected atoms are labelled for clarity.
Selected distances $(\AA)$ and angles $\left({ }^{\circ}\right)$ : Zn-C(1) = 1.971(3), Zn-C(21) = 1.935(3), $Z n \cdots F(23)=2.609(2), C(1)-Z n-C(21)=169.3(1)$.

Cation (CAAC) $\mathrm{Zn}-\mathrm{Me}^{+}\left(5^{+}\right)$cleanly reacts with $\mathrm{B}\left(\mathrm{C}_{6} \mathrm{~F}_{5}\right)_{3}$ to quantitatively yield the more Lewis acidic cation (CAAC) $\mathrm{Zn}$ $\mathrm{C}_{6} \mathrm{~F}_{5}{ }^{+}\left(7^{+}\right.$, Scheme 3), through a $\mathrm{Me} / \mathrm{C}_{6} \mathrm{~F}_{5}$ ligand exchange reaction. Cation $7^{+}$, isolated as a $\mathrm{B}\left(\mathrm{C}_{6} \mathrm{~F}_{5}\right)_{4}^{-}$salt $(50 \%$ yield $)$, crystallizes as $7^{+} / \mathrm{B}\left(\mathrm{C}_{6} \mathrm{~F}_{5}\right)_{4}{ }^{-}$ions in close contact (Figure 5) with, for instance, a rather short $Z n \cdots F(23)(2.609(2) \AA]$ well below the sum of van der Waals radii of $F$ and $Z n$. The structural and bonding parameters are overall very similar to those of $[5]\left[B\left(C_{6} F_{5}\right)_{4}\right]$. DOSY NMR data for $[7]\left[B\left(C_{6} F_{5}\right)_{4}\right]$ support the persistence of ion pairs in solution $\left(\mathrm{C}_{6} \mathrm{D}_{5} \mathrm{Br}\right.$, room temperature) with an estimated hydrodynamic volume $\left(1343 \AA^{3}\right.$, Figure S25, SI) nearly identical to the evaluated volume of $[7]\left[B\left(\mathrm{C}_{6} \mathrm{~F}_{5}\right)_{4}\right]$ in the solid state $\left(1325 \AA^{3}\right.$, Figure $\left.\mathrm{S} 26, \mathrm{SI}\right) .{ }^{[21]}$ In addition, the proximity of $7^{+}$and $\mathrm{B}\left(\mathrm{C}_{6} \mathrm{~F}_{5}\right)_{4}{ }^{-}$ions in solution is further supported by $2 \mathrm{D}{ }^{1} \mathrm{H}-$ ${ }^{19} \mathrm{~F}$ HOESY data (Figure S27, SI). Noticeably, cation $7^{+}$, stable for days in $\mathrm{CD}_{2} \mathrm{Cl}_{2}$ at room temperature, is thus significantly more robust than its $\mathrm{Zn}-\mathrm{Me}^{+}$analogue.

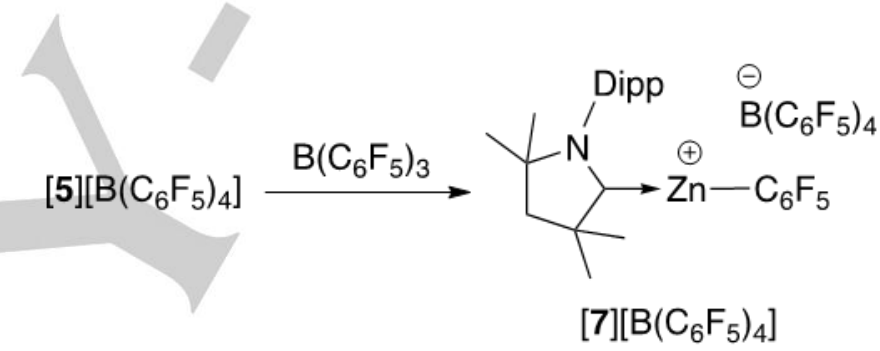

Scheme 3. Synthesis of $(C A A C) Z n-C_{6} F_{5}{ }^{+}$as a $B\left(C_{6} F_{5}\right)_{4}{ }^{-}$salt $[7]\left[B\left(C_{6} F_{5}\right)_{4}\right]$

Electronic structure and Lewis acidity assessment of cations $5^{+}$and $7^{+}$. The electronic features of Lewis acidic cations $5^{+}$and $7^{+}$were estimated through DFT calculations (BLYP/6-31+G**). In particular, the LUMO energy level of such Lewis acids may correlate to their reactivity/electrophilicity. ${ }^{[2,23,24]}$ The LUMO of cations $5^{+}$and $7^{+}$ (-5.53 and $-5.86 \mathrm{eV}$, respectively; Figure 6 ) features a $\pi$-bonding interaction between the $\mathrm{C}_{\mathrm{CAAC}}$ atom and one of the empty $p$ orbitals on $\mathrm{Zn}(\mathrm{II})$ and is significantly lower in energy than that of the $\mathrm{NHC}$ analogue (IDipp)Zn- $\mathrm{R}^{+}$(-4.61 and $-4.91 \mathrm{eV}$ for $\mathrm{R}=\mathrm{Me}$, $\mathrm{C}_{6} \mathrm{~F}_{5}$, respectively). ${ }^{[14 \mathrm{~b}]}$ The latter reflects the stronger $\pi$ accepting character of CAAC (vs. NHC ligand) and should enhance the reactivity of such cations provided orbital control is at play to some extent in these systems. NBO analysis of cations $5^{+}$and $7^{+}$(Table S2, SI) are consistent with $\mathrm{Zn}-\mathrm{C}_{\mathrm{CAAC}}$ and $\mathrm{Zn}-\mathrm{R}$ bonds being covalent with a strong ionic character (Wiberg indexes ranging from 0.38 to 0.64 ). The charge at $\mathrm{Zn}$ (II) (1.18 for $\mathbf{5}^{+}$and 1.20 for $\mathbf{7}^{+}$) is similar to those in $\mathrm{NHC}-\mathrm{Zn}$ analogues. 


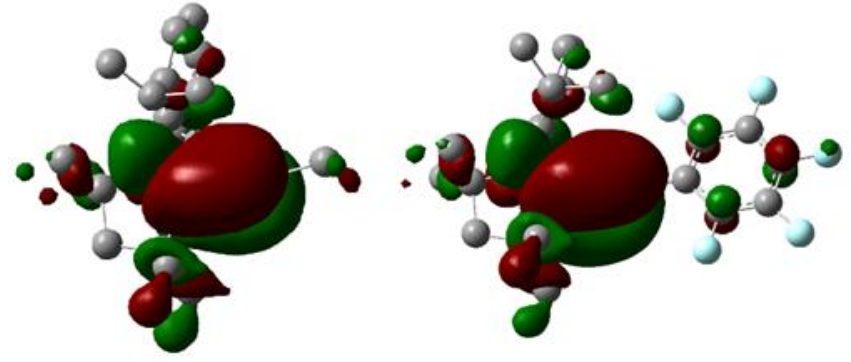

Figure 6. DFT-computed (BLYP/6-31+G**) LUMO of $\mathbf{5}^{+}$(left, $-5.53 \mathrm{eV}$ ) and $\mathbf{7}^{*}$ (right, $-5.86 \mathrm{eV}$ ).

The Lewis acidity of cations $5^{+}$and $7^{+}$was experimentally assessed using the Gutmann-Beckett method, which uses the ${ }^{31} \mathrm{P}$ NMR chemical shift difference between coordinated and free $\mathrm{Et}_{3} \mathrm{P}=\mathrm{O}$ to quantify Lewis acidity. ${ }^{[25]}$ According to these measurements, the Lewis acidity of the $\mathrm{Zn}-\mathrm{Me}$ cation $\mathbf{5}^{+}$is higher than that of (IDipp) $\mathrm{Zn}-\mathrm{Me}^{+}$, comparable to $\mathrm{Zn}\left(\mathrm{C}_{6} \mathrm{~F}_{5}\right)_{2}$ but lower than that of $\mathrm{B}\left(\mathrm{C}_{6} \mathrm{~F}_{5}\right)_{3}\left[\Delta \delta^{31} \mathrm{P}\left(\mathrm{CD}_{2} \mathrm{Cl}_{2}\right)=16.5,9.5,17.2\right.$, $26.4 \mathrm{ppm}$ for $\mathbf{5}^{+}, \quad(\mathrm{IDipp}) \mathrm{Zn}-\mathrm{Me}^{+}, \mathrm{Zn}\left(\mathrm{C}_{6} \mathrm{~F}_{5}\right)_{2}$ and $\mathrm{B}\left(\mathrm{C}_{6} \mathrm{~F}_{5}\right)_{3}$, respectively], albeit within the limit of validity of such a method. ${ }^{[26]}$ As expected, cation $7^{+}$is a stronger Lewis acid than $5^{+}$and compares to $\mathrm{B}\left(\mathrm{C}_{6} \mathrm{~F}_{5}\right)_{3}$ and (IDipp) $\mathrm{Zn}-\mathrm{C}_{6} \mathrm{~F}_{5}{ }^{+}\left[\Delta \delta^{31} \mathrm{P}\right.$ $\left(\mathrm{CD}_{2} \mathrm{Cl}_{2}\right)=21.5,26.4$ and $24.7 \mathrm{ppm}$ for $7^{+}, \mathrm{B}\left(\mathrm{C}_{6} \mathrm{~F}_{5}\right)_{3}$ and (IDipp) $\mathrm{Zn}-\mathrm{C}_{6} \mathrm{~F}_{5}{ }^{+}$]. The Fluoride Affinity Ion (FIA) of cations $5^{+}$ and $7^{+}$was also evaluated through computation (via a known methodology, see $\mathrm{SI}$ ), since it may be a reliable probe to estimate the Lewis acidity of strong/hard Lewis acids. ${ }^{[24,27]} \mathrm{FIA}$ calculations agree with $5^{+}$and $7^{+}$being more Lewis acidic than $\mathrm{B}\left(\mathrm{C}_{6} \mathrm{~F}_{5}\right)_{3}\left[\mathrm{FIA}=146,158\right.$ and $106 \mathrm{kcal} \mathrm{mol}^{-1}$ for $\mathbf{5}^{+}, \mathbf{7}^{+}$and $\mathrm{B}\left(\mathrm{C}_{6} \mathrm{~F}_{5}\right)_{3}$, respectively] and of comparable strength to (IDipp) Zn$\mathrm{Me}^{+}$and (IDipp) $\mathrm{Zn}-\mathrm{C}_{6} \mathrm{~F}_{5}{ }^{+}$, respectively.

Several recent reports on various main group heteroelement/metal electrophilic species showed that their Lewis acidity may correlate with the LUMO energy level. ${ }^{[22,24]}$ However, based on our results, such correlation does not apply to the present carbene-stabilized $\mathrm{Zn}$ (II) cations (carbene $=\mathrm{NHC}$, CAAC) since the lower lying LUMO of CAAC cations $5^{+}$and $7^{+}$ (vs. NHC analogues) little affects their Lewis acidity, albeit within the limit of validity of the estimation methods.

Hydrosilylation catalysis with cation $7^{+}$. Cations $5^{+}$and $7^{+}$ were first tested as alkene and alkyne hydrosilylation to probe their ability for small molecules activation. No reaction was observed using the less Lewis acidic $\mathrm{Zn}-\mathrm{Me}^{+}$as catalyst $\left(5^{+}\right.$, mol $5 \%$ ) in the presence of $\mathrm{HSiEt}_{3}$ and 1-hexene under the studied conditions $\left(\mathrm{CD}_{2} \mathrm{Cl}_{2}, \mathrm{RT}, 24 \mathrm{~h}\right)$. In contrast, under identical conditions, the stronger Lewis acid $7^{+}$cleanly and quantitatively hydrosilylates 1-hexene at room temperature to selectively afford the anti-Markovnikov product, triethyl(hexyl)silane (8, 95\% conv., $\mathrm{CD}_{2} \mathrm{Cl}_{2}, \mathrm{RT}, 28 \mathrm{~h}$, Scheme 4), as deduced from ${ }^{1} \mathrm{H}$ NMR data and comparison with literature data. The absence of any hydrosilylation activity with cation $5^{+}$and the fact that cation $7^{+}$ retains its integrity as the catalysis proceeds (as ${ }^{1} \mathrm{H}$ NMR monitored) strongly suggest a Lewis-acid-type catalysis as observed with borane catalysts. ${ }^{[28]}{ }^{1} \mathrm{H}$ NMR monitoring experiments $\left(\mathrm{CD}_{2} \mathrm{Cl}_{2}, \mathrm{RT}\right)$ of $1 / 1$ mixtures of $7^{+} / \mathrm{HSiEt}_{3}, 7^{+} / 1$ hexene and a $1 / 1 / 1 \quad 7^{+} / \mathrm{HSiEt}_{3} / 1$-hexene mixture showed no observable interaction between $7^{+}$and the substrates prior to product formation. Cation $7^{+}(\mathrm{mol} 5 \%)$ also mediates alkyne hydrosilylation catalysis with the fast consumption of a $1 / 1$ $\mathrm{HSiEt}_{3} / 1$-octyne mixture to afford alkenylsilane (Z)-triethyl(oct-1en-1-yl)silane (9, 40\% conv., $\mathrm{CD}_{2} \mathrm{Cl}_{2}, \mathrm{RT}, 1 \mathrm{~h}$, Scheme 4) along with uncharacterized hydrosilylation products. Cation $7^{+}$thus lies among the rare $\mathrm{Zn}$-based catalysts able to mediate alkene/alkyne hydrosilylation catalysis.

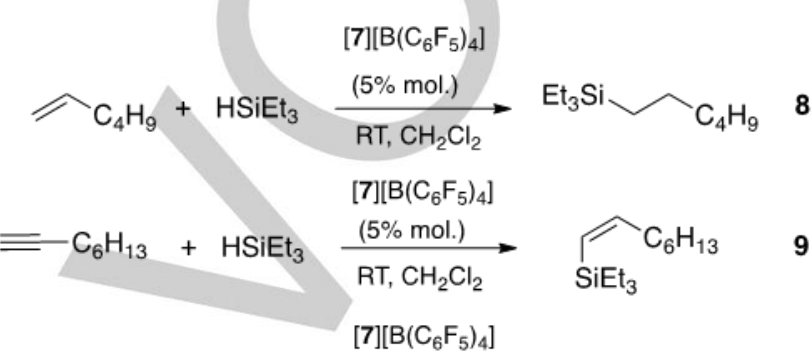

$$
\begin{aligned}
& \mathrm{CO}_{2}(1.5 \mathrm{~atm})+\mathrm{HSiEt}_{3} \underset{90{ }^{\circ} \mathrm{C}, \mathrm{PhBr}}{\stackrel{(5 \% \mathrm{~mol})}{\longrightarrow}} \quad 3 / 1 \mathrm{MeOSiEt}_{3} / \mathrm{CH}_{4}
\end{aligned}
$$

Scheme 4. Hydrosilylation reactions catalyzed by $[7]\left[B\left(C_{6} F_{5}\right)_{4}\right]$.

Metal-catalyzed $\mathrm{CO}_{2}$ hydrosilylation, preferably with cheap and non-toxic organometallics, is currently attracting considerable attention as an efficient route to $\mathrm{CO}_{2}$-derived small molecules with added value such as $\mathrm{HCO}_{2} \mathrm{SiR}_{3}, \mathrm{R}_{3} \mathrm{SiO}-\mathrm{CH}_{2}-\mathrm{OSiR}_{3}$, $\mathrm{MeOSiR}_{3}$ (formate-, aldehyde- and methanol-equivalent, respectively) and $\mathrm{CH}_{4}{ }^{[29]}$ Only a few $\mathrm{Zn}$-based catalysts for $\mathrm{CO}_{2}$ functionalization have thus far been developed. ${ }^{[14,30]}$ Cations $\mathbf{5}^{+}$ and $7^{+}$were thus tested as potential $\mathrm{CO}_{2}$ functionalization catalysts. CAAC-Zn cation $\mathbf{5}^{+}$is unreactive towards $\mathrm{CO}_{2}(1.5$ atm) in the presence of $\mathrm{HSiEt}_{3}$ under the studied conditions (mol $5 \%$ of $5^{+}, \mathrm{C}_{6} \mathrm{D}_{5} \mathrm{Br}, 90{ }^{\circ} \mathrm{C}, 24 \mathrm{~h}$ ). In contrast, the more Lewis acidic cation $7^{+}$catalyzes $\mathrm{CO}_{2}$ hydrosilylation to a $3 / 1$ MeOSiEt ${ }_{3} / \mathrm{CH}_{4}$ mixture $\left(\mathrm{C}_{6} \mathrm{D}_{5} \mathrm{Br}, 90{ }^{\circ} \mathrm{C}\right.$, complete $\mathrm{HSiEt}_{3}$ consumption after $37 \mathrm{~h}$ ) along with $\mathrm{Et}_{3} \mathrm{SiOSiEt}_{3}$ as a sideproduct. ${ }^{1} \mathrm{H}$ NMR monitoring experiments $\left(\mathrm{C}_{6} \mathrm{D}_{5} \mathrm{Br}, 90{ }^{\circ} \mathrm{C}\right)$ showed that cation $7^{+}$is unreactive with $\mathrm{CO}_{2}$ or $\mathrm{HSiEt}_{3}$ on their own, exhibits no observable interaction with a $1 / 1 \mathrm{CO}_{2} / \mathrm{HSiEt}_{3}$ mixture (prior to hydrosilylation product formation) and retains its integrity as the catalysis proceeds. A Lewis-acid-type mechanism is thus likely operative in the present $\mathrm{Zn}$ system, as that recently and thoroughly described in $\mathrm{CO}_{2}$ hydrosilylation by a $\mathrm{B}\left(\mathrm{C}_{6} \mathrm{~F}_{5}\right)_{3} / \mathrm{Al}\left(\mathrm{C}_{6} \mathrm{~F}_{5}\right)_{3}$ tandem catalyst. ${ }^{[31]}$

For further insight into the $\mathrm{CO}_{2}$ hydrosilylation mediated by cation $7^{+}$, the initial $\mathrm{CO}_{2}$ activation/functionalization was DFTcomputed (B3LYP/6-31+G**) and the calculations agree with a Lewis-acid-type mechanism. As depicted in Figure 7, the reaction is best computed through encounter complex $\mathrm{VII}-\mathrm{CO}_{2}$ $\left(\Delta \mathrm{G}=11.9 \mathrm{kcal} . \mathrm{mol}^{-1}\right.$ from isolated model cation VII, $\mathrm{CO}_{2}$ and $\mathrm{HSiEt}_{3}$; Figure $\left.\mathrm{S} 39, \mathrm{SI}\right)$ and then transition state $\mathrm{TS}-\mathrm{VII}-\mathrm{CO}_{2}(\Delta \mathrm{G}$ $=31.8 \mathrm{kcal} \cdot \mathrm{mol}^{-1}$; Figure $\left.\mathrm{S} 40, \mathrm{SI}\right)$, in which the $H-\mathrm{Si}$ hydride 
undergoes a nucleophilic backside attack at the $\mathrm{Zn}$-coordinated $\mathrm{CO}_{2}$ moiety. The formation of the $\mathrm{HCO}_{2} \mathrm{SiEt}_{3}$ adduct $\mathbf{X}$ (Figure $\mathrm{S} 41, \mathrm{SI})$ is then strongly favored thermodynamically $(\Delta \mathrm{G}=-16.4$ $\left.\mathrm{kcal} . \mathrm{mol}^{-1}\right)$, which certainly drives the reaction to completion. The estimated energy barrier for $\mathrm{CO}_{2}$ functionalization $(\Delta \mathrm{G}=31.8$ $\mathrm{kcal} . \mathrm{mol}^{-1}$ ) is in line with experimental data.

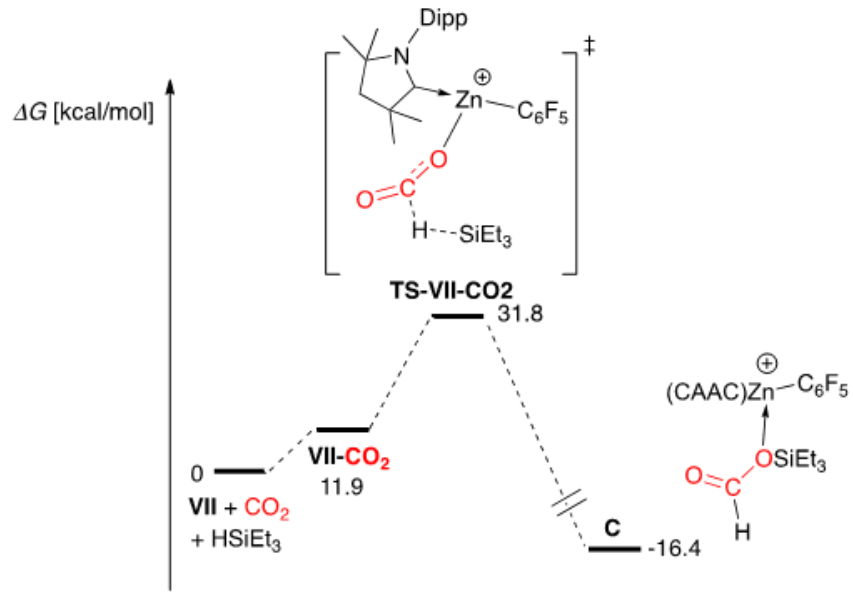

Figure 7. DFT-computed (B3LYP/6-31+ $\mathrm{G}^{* *}, \mathrm{PhBr}$ ) reaction profile for initial $\mathrm{CO}_{2}$ hydrosilylation catalyzed by model cation VII.

\section{Summary - Conclusions}

Combining $\mathrm{Zn}(\mathrm{II})$ dialkyl species such as $\mathrm{ZnMe}_{2}$ with CAAC carbene may afford highly reactive/instable species but also eventually lead to robust CAAC-supported Zn(II) Lewis acids able to catalyze transformations of topical interest. Contrasting with the stability of $(\mathrm{NHC}) \mathrm{ZnR}_{2}(\mathrm{R}=\mathrm{Me}, \mathrm{Et})$ species, CAAC adduct of $\mathrm{ZnMe}_{2}$ (2) is thermally unstable to readily undergo a carbene insertion into the $\mathrm{Zn}-\mathrm{Me}$ bond to yield the $\mathrm{ZnX}$-type species 3. Such reactivity arises from the enhanced electrophilicity of the CAAC carbene atom (vs. that in NHC). Despite its limited stability, adduct 2 may be cleanly ionized to robust two-coordinate (CAAC) $\mathrm{Zn}-\mathrm{Me}^{+}$cation $\left(5^{+}\right)$and derived into (CAAC) Zn- $\mathrm{C}_{6} \mathrm{~F}_{5}{ }^{+}\left(\mathbf{7}^{+}\right)$, thus showing the suitability of CAAC for the stabilization of highly reactive oxophilic organometallics such as $[\mathrm{Zn}-\mathrm{Me}]^{+}$and $\left[\mathrm{Zn}-\mathrm{C}_{6} \mathrm{~F}_{5}\right]^{+}$moieties. As estimated from experimental and calculations data, cations $5^{+}$and $7^{+}$are highly Lewis acidic species and, as such, cation $7^{+}$was successfully exploited in alkene, alkyne and $\mathrm{CO}_{2}$ hydrosilylation catalysis. Despite a significantly lower lying LUMO for cation $7^{+}$vs. NHC analogue (IDipp) $\mathrm{Zn}-\mathrm{C}_{6} \mathrm{~F}_{5}{ }^{+}$, the observed reactivity and estimated Lewis acidity of both cations are comparable, clearly indicating that the reactivity of such electrophilic $\mathrm{Zn}$ (II) cations is solely under charge control and that the electronic differences between CAAC and NHC ligands little affect the reactivity of the derived $\mathrm{Zn}(\mathrm{II})$ cations.

\section{Experimental Section}

Material, reagents and methods. All work was performed under $\mathrm{N}_{2}$ atmosphere using standard glove box techniques. Solvents were stored over $4 \AA$ molecular sieves and were freshly distilled under argon from sodium-benzophenone or $\mathrm{CaH}_{2}$, or they were dispensed from a commercial solvent purification system. Deuterated solvents were used as received and stored over $4 \AA$ molecular sieves. NMR spectra were recorded on Bruker Avance I - $300 \mathrm{MHz}$, Bruker Avance III - $400 \mathrm{MHz}$, Bruker Avance II - $500 \mathrm{MHz}$ and Bruker Avance III - $600 \mathrm{MHz}$ spectrometers. NMR chemical shift values were determined relative to the residual protons in toluene- $d^{8}, C_{6} D_{6}$ and $C_{6} D_{5} B r$ as internal reference for ${ }^{1} \mathrm{H}(\delta$ of the most upfield signal $=2.08,7.16,6.95 \mathrm{ppm})$ and ${ }^{13} \mathrm{C}\left\{{ }^{1} \mathrm{H}\right\}(\delta$ of the most downfield signal $=137.48,128.06,130.89 \mathrm{ppm})$. $\mathrm{HSiEt}_{3}$, $\mathrm{Et}_{3} \mathrm{PO}$, 1-hexene and 1-octyne were purchased from Aldrich. 1-hexene and 1-octyne were stored over molecular sieves $(4 \AA)$ for at least $24 \mathrm{~h}$ prior to use. $\mathrm{ZnMe}_{2}$ and $\left[\mathrm{CPh}_{3}\right]\left[\mathrm{B}\left(\mathrm{C}_{6} \mathrm{~F}_{5}\right)_{4}\right]$ were obtained from Strem Chemicals Inc. $\mathrm{B}\left(\mathrm{C}_{6} \mathrm{~F}_{5}\right)_{3}$ was obtained from $\mathrm{TCl}$ Europe and recrystallized from cold pentane prior to use. Cyclic (alkyl)(amino)carbene (CAAC) 1 was prepared according to a literature procedure. ${ }^{[3 \mathrm{a}]}$

Generation of adduct (CAAC)ZnMe ${ }_{2}$ (2). In toluene: To a $-35{ }^{\circ} \mathrm{C}$ solution of $\mathrm{ZnMe}_{2}(13.4 \mathrm{mg}, 11 \mu \mathrm{L}, 140 \mu \mathrm{mol})$ in deuterated toluene $(0.25$ $\mathrm{mL}$ ) was added dropwise a $-35^{\circ} \mathrm{C}$ solution of CAAC (40 mg, $\left.140 \mu \mathrm{mol}\right)$ in deuterated toluene $(0.25 \mathrm{~mL})$ giving a colorless solution. The mixture was then immediately transferred in a J-Young NMR tube and a ${ }^{1} \mathrm{H}$ NMR spectrum at $-80^{\circ} \mathrm{C}$ was immediately recorded, showing the quantitative formation of (CAAC) $\mathrm{ZnMe}_{2}(2)$ on the basis of ${ }^{1} \mathrm{H}$ and ${ }^{13} \mathrm{C}$ NMR data. Adduct 2 is stable in toluene at $-40{ }^{\circ} \mathrm{C}$ for $12 \mathrm{~h}$ but decomposes fast at room temperature, precluding its isolation in a pure form. Likewise, adduct $\mathbf{2}$ is also thermally unstable in the solid state. In pentane: the addition of a pentane solution $(5 \mathrm{~mL})$ of $\mathrm{ZnMe}_{2}(20.1 \mathrm{mg}, 16.5 \mu \mathrm{L}, 210$ $\mu \mathrm{mol})$, cooled at $-40{ }^{\circ} \mathrm{C}$, to a pentane solution of CAAC $1(60 \mathrm{mg}, 210$ $\mu \mathrm{mol})$, also cooled at $-40{ }^{\circ} \mathrm{C}$, resulted in the immediate precipitation of a colorless solid, presumably adduct CAACZnMe 2 (2). The collected colorless solid is however unstable under vacuum (turning into a black insoluble residue within a few minutes), thus preventing further characterization. ${ }^{1} \mathrm{H}$ NMR $\left(600 \mathrm{MHz}\right.$, tol- $\left.\mathrm{d}^{8}, 193 \mathrm{~K}\right): \delta(\mathrm{ppm}) 7.06(\mathrm{t}, \mathrm{J}=$ $7.8 \mathrm{~Hz}, 1 \mathrm{H}, \mathrm{CH}-\mathrm{Ar}$ ), 6.85 (d, $J=7.8 \mathrm{~Hz}, 2 \mathrm{H}, \mathrm{CH}-\mathrm{Ar}$ ), 2.70 (hept, $J=6.7$ $\mathrm{Hz}, 2 \mathrm{H}, \mathrm{CH}-{ }^{\prime} \mathrm{Pr}$ ), 1.32 (s, $6 \mathrm{H}, \mathrm{NC}(\mathrm{Me})_{2} \mathrm{CH}_{2} \mathrm{C}(\mathrm{Me})_{2} \mathrm{CN}$ ), 1.27 (d, J = 6.7 Hz, $6 \mathrm{H}, \mathrm{CH}_{3}{ }^{-} \mathrm{Pr}$ ), 1.22 (s, 2H, NC(Me) $)_{2} \mathrm{CH}_{2} \mathrm{C}(\mathrm{Me})_{2} \mathrm{CN}$ ), 1.08 (d, J = 6.7 Hz, $6 \mathrm{H}, \mathrm{CH}_{3}{ }^{-} \mathrm{Pr}$ ), 0.79 (s, $6 \mathrm{H}, \mathrm{NC}(\mathrm{Me})_{2} \mathrm{CH}_{2} \mathrm{C}(\mathrm{Me})_{2} \mathrm{CN}$ ), -0.28 (s, 6H, ZnMe). ${ }^{13} \mathrm{C}$ NMR (150 MHz, Tol-d8, $\left.193 \mathrm{~K}\right): \delta(\mathrm{ppm}) 267.6\left(\mathrm{C}_{\text {carbene }}-\mathrm{Zn}\right), 144.9$

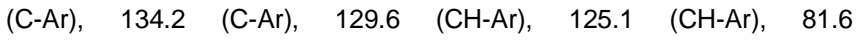
$\begin{array}{llll}\left(\mathrm{NC}(\mathrm{Me})_{2} \mathrm{CH}_{2} \mathrm{C}(\mathrm{Me})_{2} \mathrm{CN}\right), & 55.7 \quad\left(\mathrm{NC}(\mathrm{Me})_{2} \mathrm{CH}_{2} \mathrm{C}(\mathrm{Me})_{2} \mathrm{CN}\right), & 48.9\end{array}$ (NC(Me) $\left.{ }_{2} \mathrm{CH}_{2} \mathrm{C}(\mathrm{Me})_{2} \mathrm{CN}\right), 28.9$ ( $\left.\mathrm{CH}-{ }^{i} \mathrm{Pr}\right), 28.1\left(\mathrm{NC}(\mathrm{Me})_{2} \mathrm{CH}_{2} \mathrm{C}(\mathrm{Me})_{2} \mathrm{CN}\right)$, $\left.27.9\left(\mathrm{NC}(\mathrm{Me})_{2} \mathrm{CH}_{2} \mathrm{C}(\mathrm{Me})_{2} \mathrm{CN}\right)\right), 26.6\left(\mathrm{CH}_{3}{ }^{-} \mathrm{Pr}\right), 23.4\left(\mathrm{CH}_{3}{ }^{-} \mathrm{Pr}\right), \quad-3.76$ (ZnMe).

NMR characterization of (CAAC-Me)Zn-Me (3). In a J-Young NMR tube, the decomposition of adduct (CAAC) $\mathrm{ZnMe}_{2}$ (2) in deuterated toluene was monitored by variable temperature ${ }^{1} \mathrm{H}$ and ${ }^{13} \mathrm{C}$ NMR. After 1 $\mathrm{h}$ at room temperature, $83 \%$ of (CAAC) $\mathrm{ZnMe}_{2}$ was consumed to yield (CAAC-Me)ZnMe (3) as the major product (72\% conversion, relative to $\mathrm{CAAC}$, by ${ }^{1} \mathrm{H}$ NMR). Compound 3 is instable at room temperature to decompose to organic residues 4 and 4'(vide infra), which precluded the isolation of $\mathbf{3}$ in a pure form. NMR signals assignment done on the basis of 1D (1H, 13C) and 2D (HSQC, HMBC, COSY, NOESY) are consistent with the proposed formulation for 3. ${ }^{1} \mathrm{H}$ NMR $(600 \mathrm{MHz}$, Tol-d8, $233 \mathrm{~K})$ : $\delta$ (ppm) 7.14-7.11 (m, 2H, CH-Ar), 6.96 (dd, $J=5.7,3.8 \mathrm{~Hz}, 1 \mathrm{H}, \mathrm{CH}-\mathrm{Ar}$ ), 4.21 (hept, $J=5.9 \mathrm{~Hz}, 1 \mathrm{H}, \mathrm{CH}-{ }^{i} \mathrm{Pr}$ ), 3.54 (hept, $J=5.9 \mathrm{~Hz}, 1 \mathrm{H}, \mathrm{CH}-{ }^{i} \mathrm{Pr}$ ), $1.75\left(\mathrm{~d}, J=13.1 \mathrm{~Hz}, 1 \mathrm{H}, \mathrm{NC}(\mathrm{Me})_{2} \mathrm{CH}_{2} \mathrm{C}(\mathrm{Me})_{2} \mathrm{CN}\right), 1.54(\mathrm{~d}, J=13.1 \mathrm{~Hz}$, $\left.1 \mathrm{H}, \mathrm{NC}(\mathrm{Me})_{2} \mathrm{CH}_{2} \mathrm{C}(\mathrm{Me})_{2} \mathrm{CN}\right), 1.29\left(\mathrm{~d}, J=6.7 \mathrm{~Hz}, 3 \mathrm{H}, \mathrm{CH}_{3}{ }^{-} \mathrm{Pr}\right), 1.26$ (d, J $\left.=6.7 \mathrm{~Hz}, 3 \mathrm{H}, \mathrm{CH}_{3}{ }^{-} \mathrm{Pr}\right), 1.21$ (d, $\left.J=6.7 \mathrm{~Hz}, 3 \mathrm{H}, \mathrm{CH}_{3}{ }^{-} \mathrm{Pr}\right), 1.16(\mathrm{~d}, J=6.7$ $\mathrm{Hz}, 3 \mathrm{H}, \mathrm{CH}_{3}{ }^{i} \mathrm{Pr}$ ), 1.16 (s, 3H, $\left.\mathrm{NC}(\mathrm{Me})_{2} \mathrm{CH}_{2} \mathrm{C}(\mathrm{Me})_{2} \mathrm{CN}\right), 1.11$ (s, 3H, 
$\left.\mathrm{NC}(\mathrm{Me})_{2} \mathrm{CH}_{2} \mathrm{C}(\mathrm{Me})_{2} \mathrm{CN}\right), 1.09$ (s, 3H, $\mathrm{NC}(\mathrm{Me})_{2} \mathrm{CH}_{2} \mathrm{C}(\mathrm{Me})_{2} \mathrm{CN}$ ), 1.06 (s, $3 \mathrm{H}, \mathrm{NC}(\mathrm{Me})_{2} \mathrm{CH}_{2} \mathrm{C}(\mathrm{Me})_{2} \mathrm{CN}, 0.87$ (s, 3H, C(Me)ZnMe), -0.23 (s, 3H $\mathrm{ZnMe}) \cdot{ }^{13} \mathrm{C}$ NMR $\left(150 \mathrm{MHz}\right.$, Tol-d $\left.{ }^{8}, 233 \mathrm{~K}\right): \delta$ (ppm) 153.96 (C-Ar), 150.23 (C-Ar), 138.1 (C-Ar), 126.81 (CH-Ar), $125.0(\mathrm{CH}-\mathrm{Ar}), 124.11(\mathrm{CH}-$ $\mathrm{Ar}), \quad 74.86 \quad(\mathrm{C}(\mathrm{Me}) \mathrm{ZnMe}), \quad 60.23 \quad\left(\mathrm{NC}(\mathrm{Me})_{2} \mathrm{CH}_{2} \mathrm{C}(\mathrm{Me})_{2} \mathrm{CN}\right), \quad 58.71$ ( $\left.\mathrm{NC}(\mathrm{Me})_{2} \mathrm{CH}_{2} \mathrm{C}(\mathrm{Me})_{2} \mathrm{CN}\right)$, $31.28\left(\mathrm{CH}-{ }^{-} \mathrm{Pr}\right), 30.85\left(\mathrm{NC}(\mathrm{Me})_{2} \mathrm{CH}_{2} \mathrm{C}(\mathrm{Me})_{2} \mathrm{CN}\right)$, $29.85\left(\mathrm{NC}(\mathrm{Me})_{2} \mathrm{CH}_{2} \mathrm{C}(\mathrm{Me})_{2} \mathrm{CN}\right), 29.71\left(\mathrm{NC}(\mathrm{Me})_{2} \mathrm{CH}_{2} \mathrm{C}(\mathrm{Me})_{2} \mathrm{CN}\right), 27.32$ $\left(\mathrm{CH}^{-}{ }^{-} \mathrm{Pr}\right), 26.35\left(\mathrm{CH}_{3}{ }^{-} \mathrm{Pr}\right), 26.22\left(\mathrm{CH}_{3}{ }^{-} \mathrm{Pr}\right), 24.19\left(\mathrm{CH}_{3}{ }^{-} \mathrm{Pr}\right), 23.50\left(\mathrm{CH}_{3}\right.$ $\left.{ }^{i} \mathrm{Pr}\right), 22.95\left(\mathrm{NC}(\mathrm{Me})_{2} \mathrm{CH}_{2} \mathrm{C}(\mathrm{Me})_{2} \mathrm{CN}\right), 19.49(\mathrm{C}(\mathrm{Me}) \mathrm{ZnMe}),-5.73(\mathrm{ZnMe})$

X-ray Crystallographic characterization of (CAAC-Me)Zn-Me (3). Adduct $\mathrm{CAACZnMe}_{2}$ (2) was generated in situ as described above in pentane at $-40{ }^{\circ} \mathrm{C}$. The mother liquor was then left $1 \mathrm{~h}$ at room temperature and was cooled down to $-35{ }^{\circ} \mathrm{C}$ for $48 \mathrm{~h}$, after which colorless crystals had formed. Their analysis through $\mathrm{X}$-ray crystallography confirmed the molecular structure of $\mathbf{3}$ as (CAAC-Me)ZnMe.

Characterization of (CAAC)ZnMe 2 decomposition products 4, 4'. A deuterated toluene solution of $(\mathrm{CAAC}) \mathrm{ZnMe}_{2}(0.140 \mathrm{mmol})$ prepared as described previously was left at room temperature for two days to monitor the decomposition process by ${ }^{1} \mathrm{H}$ NMR. During this time, adduct 2 was completely consumed, leading to the formation of a $\mathrm{Zn}$ metal precipitate, along with $\mathrm{CH}_{4}$, free $\mathrm{ZnMe}_{2}$ and three unknown CAAC derivatives. After removal of $\mathrm{Zn}$ metal, the mixture was dried under vacuum to remove $\mathrm{CH}_{4}$ and $\mathrm{ZnMe}_{2}$ affording a white solid that was solubilized in pentane and passed through a silica plug to afford white crystalline solid after solvent removal under vacuum. NMR of the mixture and high-resolution mass spectrometric data allowed the identification of the two main CAAC derivatives 4 and $\mathbf{4}^{\prime}$ in $63 \%$ and $31 \%$ conversion, respectively, relative to $\mathbf{2}$. The structure and NMR assignment for $\mathbf{4}$ and $\mathbf{4}$ are proposed on the basis of $1 \mathrm{D}(1 \mathrm{H}, 13 \mathrm{C})$ and 2D (HSQC, HMBC, COSY, NOESY) NMR data and mass spectrometric analysis.

1-(2,6-diisopropylphenyl)-2,2,4,4-tetramethyl-5-methylenepyrrolidine (4) ${ }^{1} \mathrm{H}$ NMR $\left(500 \mathrm{MHz}, \mathrm{C}_{6} \mathrm{D}_{6}, 298 \mathrm{~K}\right): \delta(\mathrm{ppm}) 7.24$ (dd, $J=7.2 \mathrm{~Hz}, 1 \mathrm{H}, \mathrm{CH}-$ Ar), $7.17\left(\mathrm{~d}, J=7.2 \mathrm{~Hz}, 2 \mathrm{H}, \mathrm{CH}-\mathrm{Ar}\right.$ ), $3.07\left(\mathrm{~s}, 1 \mathrm{H}, \mathrm{C}=\mathrm{CH}_{2}\right.$ ), 3.27 (hept, $J=$ $6.8 \mathrm{~Hz}, 2 \mathrm{H}, \quad \mathrm{CH}-\mathrm{Pr}), \quad 3.50 \quad\left(\mathrm{~s}, \quad 1 \mathrm{H}, \quad \mathrm{C}=\mathrm{CH}_{2}\right), 1.78(\mathrm{~s}, 2 \mathrm{H}$, $\left.\mathrm{NC}(\mathrm{Me})_{2} \mathrm{CH}_{2} \mathrm{C}(\mathrm{Me})_{2} \mathrm{CN}\right), 1.34$ (s, $\left.6 \mathrm{H}, \mathrm{NC}(\mathrm{Me})_{2} \mathrm{CH}_{2} \mathrm{C}(\mathrm{Me})_{2} \mathrm{CN}\right), 1.28(\mathrm{~d}, J$ $\left.=6.8 \mathrm{~Hz}, 6 \mathrm{H}, \mathrm{CH}_{3}{ }^{-} \mathrm{Pr}\right), 1.27\left(\mathrm{~d}, J=6.8 \mathrm{~Hz}, 6 \mathrm{H}, \mathrm{CH}_{3}{ }^{-} \mathrm{Pr}\right), 1.11(\mathrm{~s}, 6 \mathrm{H}$, $\left.\mathrm{NC}(\mathrm{Me})_{2} \mathrm{CH}_{2} \mathrm{C}(\mathrm{Me})_{2} \mathrm{CN}\right) \cdot{ }^{13} \mathrm{C}$ NMR (150 MHz, $\left.\mathrm{C}_{6} \mathrm{D}_{6}\right): \delta$ (ppm) 163,84 $\left(\mathrm{C}=\mathrm{CH}_{2}\right), 150.71$ (C-Ar), 134.64 (C-Ar), $124.82(\mathrm{CH}-\mathrm{Ar}), 70.88\left(\mathrm{C}=\mathrm{CH}_{2}\right)$, $63.30\left(\mathrm{NC}(\mathrm{Me})_{2} \mathrm{CH}_{2} \mathrm{C}(\mathrm{Me})_{2} \mathrm{CN}\right), 54.36\left(\mathrm{NC}(\mathrm{Me})_{2} \mathrm{CH}_{2} \mathrm{C}(\mathrm{Me})_{2} \mathrm{CN}\right), 40.92$ $\left(\mathrm{NC}(\mathrm{Me})_{2} \mathrm{CH}_{2} \mathrm{C}(\mathrm{Me})_{2} \mathrm{CN}\right), \quad 31.91 \quad\left(\mathrm{NC}(\mathrm{Me})_{2} \mathrm{CH}_{2} \mathrm{C}(\mathrm{Me})_{2} \mathrm{CN}\right), \quad 29.61$ $\left(\mathrm{NC}(\mathrm{Me})_{2} \mathrm{CH}_{2} \mathrm{C}(\mathrm{Me})_{2} \mathrm{CN}\right), 28.79\left(\mathrm{CH}^{-} \mathrm{Pr}\right), 26.82\left(\mathrm{CH}_{3}{ }^{-} \mathrm{Pr}\right), 23.89\left(\mathrm{CH}_{3}{ }^{i} \mathrm{Pr}\right)$ Ms: $\mathrm{m} / \mathrm{z} 300.2699,301.2726,302.2753$ (theoretical mass for the molecular peak of $4: 300.2647$ ).

1-(2,6-diisopropylphenyl)-5-ethylidene-2,2,4,4-tetramethylpyrrolidine (4') ${ }^{1} \mathrm{H} \mathrm{NMR}\left(500 \mathrm{MHz}, \mathrm{C}_{6} \mathrm{D}_{6}, 298 \mathrm{~K}\right): \delta(\mathrm{ppm}) 7.20(\mathrm{~d}, J=6.0 \mathrm{~Hz}, 1 \mathrm{H}, \mathrm{CH}-\mathrm{Ar})$ $7.17(\mathrm{~d}, J=6.0 \mathrm{~Hz}, 1 \mathrm{H}, \mathrm{CH}-\mathrm{Ar}$ ), 7.11 (dd, $J=6.0,6.0 \mathrm{~Hz}, 1 \mathrm{H}, \mathrm{CH}-\mathrm{Ar}$ ), 4.06 (hept, $J=6.6 \mathrm{~Hz}, 1 \mathrm{H}, \mathrm{CH}-{ }^{i} \mathrm{Pr}$ ), $3.65(\mathrm{q}, J=6.4 \mathrm{~Hz}, 1 \mathrm{H}, \mathrm{C}=\mathrm{C}(\mathrm{Me}) H$ ), 3.41 (hept, $\left.J=6.9 \mathrm{~Hz}, 1 \mathrm{H}, \mathrm{CH}-{ }^{-} \mathrm{Pr}\right), 1.80(\mathrm{~d}, J=12.7 \mathrm{~Hz}, 1 \mathrm{H}$, $\left.\mathrm{NC}(\mathrm{Me})_{2} \mathrm{CH}_{2} \mathrm{C}(\mathrm{Me})_{2} \mathrm{CN}\right), \quad 1.74 \quad(\mathrm{~d}, \quad J=12.7 \quad \mathrm{~Hz}, \quad 1 \mathrm{H}$, $\left.\mathrm{NC}(\mathrm{Me})_{2} \mathrm{CH}_{2} \mathrm{C}(\mathrm{Me})_{2} \mathrm{CN}\right), 1.32\left(\mathrm{~d}, J=6.6 \mathrm{~Hz}, 3 \mathrm{H}, \mathrm{CH}_{3}{ }^{-} \mathrm{Pr}\right), 1.27$ (d, $J=$ $\left.6.9 \mathrm{~Hz}, \quad 3 \mathrm{H}, \quad \mathrm{CH}_{3}{ }^{-} \mathrm{Pr}\right), \quad 1.17\left(\mathrm{~m}, \quad 6 \mathrm{H}, \quad \mathrm{CH}_{3}{ }^{-} \mathrm{Pr}\right), \quad 1.21 \quad(\mathrm{~s}, \quad 3 \mathrm{H}$ $\mathrm{NC}(\mathrm{Me})_{2} \mathrm{CH}_{2} \mathrm{C}(\mathrm{Me})_{2} \mathrm{CN}$ ), 1.12 (s, 3H, NC(Me $)_{2} \mathrm{CH}_{2} \mathrm{C}(\mathrm{Me})_{2} \mathrm{CN}$ ), 1.08 (s, $3 \mathrm{H}, \mathrm{NC}(\mathrm{Me})_{2} \mathrm{CH}_{2} \mathrm{C}(\mathrm{Me}){ }_{2} \mathrm{CN}$ ), 0.98 (s, 3H, NC(Me) ${ }_{2} \mathrm{CH}_{2} \mathrm{C}(\mathrm{Me}){ }_{2} \mathrm{CN}, 0.78$ (d, $J=6.4 \mathrm{~Hz}, 3 \mathrm{H}, \mathrm{C}=\mathrm{C}(\mathrm{Me}) H) \cdot{ }^{13} \mathrm{C} \mathrm{NMR}\left(150 \mathrm{MHz}, \mathrm{C}_{6} \mathrm{D}_{6}\right): \delta(\mathrm{ppm}) 153.09$ (C-Ar), $152.37(\mathrm{C}=\mathrm{C}(\mathrm{Me}) \mathrm{H}), 151.97$ (C-Ar), $138.0(\mathrm{C}-\mathrm{Ar}), 127.1$ (CH-Ar), $124.69 \quad(\mathrm{CH}-\mathrm{Ar}), \quad 124.63 \quad(\mathrm{CH}-\mathrm{Ar}), \quad 67.78 \quad(\mathrm{C}=\mathrm{C}(\mathrm{Me}) \mathrm{H}), \quad 61.10$ $\left(\mathrm{NC}(\mathrm{Me})_{2} \mathrm{CH}_{2} \mathrm{C}(\mathrm{Me})_{2} \mathrm{CN}\right), \quad 56.87 \quad\left(\mathrm{NC}(\mathrm{Me})_{2} \mathrm{CH}_{2} \mathrm{C}(\mathrm{Me})_{2} \mathrm{CN}\right), \quad 39.38$ $\left(\mathrm{NC}(\mathrm{Me})_{2} \mathrm{CH}_{2} \mathrm{C}(\mathrm{Me})_{2} \mathrm{CN}\right), 31.10\left(\mathrm{NC}(\mathrm{Me})_{2} \mathrm{CH}_{2} \mathrm{C}(\mathrm{Me})_{2} \mathrm{CN}\right), 29.56\left(\mathrm{CH}^{-} \mathrm{Pr}\right)$, $29.22\left(\mathrm{NC}(\mathrm{Me})_{2} \mathrm{CH}_{2} \mathrm{C}(\mathrm{Me})_{2} \mathrm{CN}\right), 28.12\left(\mathrm{NC}(\mathrm{Me})_{2} \mathrm{CH}_{2} \mathrm{C}(\mathrm{Me})_{2} \mathrm{CN}\right), 27.47$
( $\left.\mathrm{CH}-{ }^{-} \mathrm{Pr}\right), 26.37\left(\mathrm{CH}_{3}{ }^{-} \mathrm{Pr}\right), 25.71\left(\mathrm{CH}_{3}{ }^{-} \mathrm{Pr}\right), 24.40\left(\mathrm{CH}_{3}{ }^{-} \mathrm{Pr}\right), 24.15\left(\mathrm{CH}_{3-}\right.$ $\left.{ }^{\prime} \mathrm{Pr}\right), 24.06\left(\mathrm{NC}(\mathrm{Me})_{2} \mathrm{CH}_{2} \mathrm{C}(\mathrm{Me})_{2} \mathrm{CN}\right), 15.50 \quad(\mathrm{C}=\mathrm{C}(\mathrm{Me}) \mathrm{H}) . \quad \mathrm{Ms}: \mathrm{m} / \mathrm{z}$ 314.2543 (theoretical mass for the molecular peak of 4': 314.2803).

The $\mathrm{Zn}(0)$ was separated by decantation, washed with pentane, dried under vacuum and characterized by powder X-ray diffraction (see Fig. S16, SI), confirming its identity.

[(CAAC)Zn-Me][B( $\left.\left.\mathbf{C}_{6} \mathrm{~F}_{5}\right)_{4}\right]\left([5]\left[\mathrm{B}\left(\mathbf{C}_{6} \mathrm{~F}_{5}\right)_{4}\right]\right)$. To a $-35^{\circ} \mathrm{C}$ solution of $\mathrm{ZnMe}_{2}$ (14.08 mg, $175 \mu \mathrm{mol})$ in $\mathrm{C}_{6} \mathrm{H}_{5} \mathrm{~F}(1 \mathrm{~mL})$ is added dropwise a $-35{ }^{\circ} \mathrm{C}$ solution of CAAC $(50 \mathrm{mg}, 175 \mu \mathrm{mol})$ in $\mathrm{C}_{6} \mathrm{H}_{5} \mathrm{~F}(1 \mathrm{~mL})$ giving a colorless solution that is immediately added dropwise to a room temperature dark orange $\mathrm{C}_{6} \mathrm{H}_{5} \mathrm{~F}$ solution of $\left[\mathrm{CPh}_{3}\right]\left[\mathrm{B}\left(\mathrm{C}_{6} \mathrm{~F}_{5}\right)_{4}\right](145.4 \mathrm{mg}, 158 \mu \mathrm{mol}$ in $1 \mathrm{~mL})$ until the mixture becomes colorless, the latter indicating that $\left[\mathrm{CPh}_{3}\right]\left[\mathrm{B}\left(\mathrm{C}_{6} \mathrm{~F}_{5}\right)_{4}\right]$ has completely reacted. The solvent was then immediately removed under vacuum and the oily residue triturated with pentane $(3 \times 5 \mathrm{~mL})$ to yield a white powder. Recrystallization in $\mathrm{C}_{6} \mathrm{H}_{5} \mathrm{~F}$ /pentane at $-35^{\circ} \mathrm{C}$ afforded $[(\mathrm{CAAC}) \mathrm{Zn}-\mathrm{Me}]\left[\mathrm{B}\left(\mathrm{C}_{6} \mathrm{~F}_{5}\right)_{4}\right]$ as colorless crystals $\left(120 \mathrm{mg}, 67 \%\right.$ yield). ${ }^{1} \mathrm{H}$ NMR $\left(400 \mathrm{MHz}, \mathrm{C}_{6} \mathrm{D}_{5} \mathrm{Br}, 298 \mathrm{~K}\right): \delta 7.25$ (t, $J=7.9 \mathrm{~Hz}, 1 \mathrm{H}, \mathrm{CH}-\mathrm{Ar}$ ), 7.05 (d, $J=7.9 \mathrm{~Hz}, 2 \mathrm{H}, \mathrm{CH}-\mathrm{Ar}$ ), 2.42 (hept, $J=$ $6.8 \mathrm{~Hz}, 2 \mathrm{H}, \mathrm{CH}-\mathrm{Pr}), 1.72\left(\mathrm{~s}, 2 \mathrm{H}, \mathrm{NC}(\mathrm{Me})_{2} \mathrm{CH}_{2} \mathrm{C}(\mathrm{Me})_{2} \mathrm{CN}\right), 1.11(\mathrm{~s}, 6 \mathrm{H}$, $\left.\mathrm{NC}(\mathrm{Me})_{2} \mathrm{CH}_{2} \mathrm{C}(\mathrm{Me})_{2} \mathrm{CN}\right), 1.10\left(\mathrm{~d}, J=6.8 \mathrm{~Hz}, 6 \mathrm{H}, \mathrm{CH}_{3}{ }^{-} \mathrm{Pr}\right), 1.05(\mathrm{~s}, 6 \mathrm{H}$ $\mathrm{NC}(\mathrm{Me})_{2} \mathrm{CH}_{2} \mathrm{C}(\mathrm{Me})_{2} \mathrm{CN}$ ), 0.92 (d, $J=6.7 \mathrm{~Hz}, 6 \mathrm{H}, \mathrm{CH}_{3}{ }^{-} \mathrm{Pr}$ ), -0.70 (s, 3H, $\mathrm{ZnMe}$ ) ppm. ${ }^{19} \mathrm{~F}$ NMR (282 MHz, $\mathrm{C}_{6} \mathrm{D}_{5} \mathrm{Br}, 298 \mathrm{~K}$ ): $\delta$ (ppm) -131.64 (bd, o $\left.\mathrm{B}\left(\mathrm{C}_{6} \mathrm{~F}_{5}\right)_{4}\right),-162.06\left(\mathrm{t}, J_{F F}=21.0 \mathrm{~Hz}, p-\mathrm{B}\left(\mathrm{C}_{6} \mathrm{~F}_{5}\right)_{4}\right),-165.89\left(\mathrm{bt}, m-\mathrm{B}\left(\mathrm{C}_{6} \mathrm{~F}_{5}\right)_{4}\right)$. ${ }^{13} \mathrm{C}$ NMR (150 MHz, $\left.\mathrm{C}_{6} \mathrm{D}_{5} \mathrm{Br}, 298 \mathrm{~K}\right): \delta$ (ppm) 231.75 (carbene), 148.44 $\left(\mathrm{dm}, J_{C F}=240.9 \mathrm{~Hz}, o-\mathrm{C}_{6} \mathrm{~F}_{5}\right), 144.23(\mathrm{C}-\mathrm{Ar}), 138.30\left(\mathrm{dm}, J_{C F}=240.2 \mathrm{~Hz}\right.$, $\left.p-\mathrm{C}_{6} \mathrm{~F}_{5}\right), 136.38\left(\mathrm{dm}, J_{C F}=243.0 \mathrm{~Hz}, m-\mathrm{C}_{6} \mathrm{~F}_{5}\right), 132.62\left(\mathrm{C}_{\text {ipso }}\right), 128.63$ $(\mathrm{CH}-\mathrm{Ar}), \quad 124.59 \quad(\mathrm{CH}-\mathrm{Ar}) \quad 84.84 \quad\left(\mathrm{NC}(\mathrm{Me})_{2} \mathrm{CH}_{2} \mathrm{C}(\mathrm{Me})_{2} \mathrm{CN}\right), \quad 52.94$ $\left(\mathrm{NC}(\mathrm{Me})_{2} \mathrm{CH}_{2} \mathrm{C}(\mathrm{Me})_{2} \mathrm{CN}\right), 48.49\left(\mathrm{NC}(\mathrm{Me})_{2} \mathrm{CH}_{2} \mathrm{C}(\mathrm{Me})_{2} \mathrm{CN}\right), 28.62\left(\mathrm{CH}^{-} \mathrm{Pr}\right)$ $\left.28.05\left(\mathrm{NC}(\mathrm{Me})_{2} \mathrm{CH}_{2} \mathrm{C}(\mathrm{Me})_{2} \mathrm{CN}\right), 26.56\left(\mathrm{NC}(\mathrm{Me})_{2} \mathrm{CH}_{2} \mathrm{C}(\mathrm{Me})_{2} \mathrm{CN}\right)\right), 26.30$ $\left(\mathrm{CH}_{3}{ }^{-} \mathrm{Pr}\right), 22.30\left(\mathrm{CH}_{3}{ }^{i} \mathrm{Pr}\right), \quad-7.66(\mathrm{ZnMe})$ ppm. Anal. Calcd. For [(CAAC)Zn-Me] $\left[B\left(\mathrm{C}_{6} \mathrm{~F}_{5}\right)_{4}\right]+1$ equiv of pentane, $\mathrm{C}_{50} \mathrm{H}_{46} \mathrm{BF}_{20} \mathrm{NZn}: \mathrm{N}, 1.25$; C, 53.76; H 4.15. Found: N, 1.28; C, 53.65; H 4.19.

[(CAAC $\left.)_{2} \mathbf{Z n}-\mathrm{Me}\right]\left[\mathbf{B}\left(\mathbf{C}_{6} \mathbf{F}_{5}\right)_{4}\right] \quad\left([6]\left[B\left(\mathbf{C}_{6} \mathbf{F}_{5}\right)_{4}\right]\right)$. To a $-35{ }^{\circ} \mathrm{C}$ solution of $\mathrm{ZnMe}_{2}(14.08 \mathrm{mg}, 157 \mu \mathrm{mol})$ in $\mathrm{PhF}(1 \mathrm{~mL})$ is added dropwise a $-35^{\circ} \mathrm{C}$ solution of CAAC $(50 \mathrm{mg}, 157 \mu \mathrm{mol})$ in $\mathrm{PhF}(1 \mathrm{~mL})$ giving a colorless solution. A dark orange $\mathrm{PhF}$ solution $(1 \mathrm{~mL})$ of $\left[\mathrm{CPh}_{3}\right]\left[\mathrm{B}\left(\mathrm{C}_{6} \mathrm{~F}_{5}\right)_{4}\right]$ (145.4 $\mathrm{mg}, 0.157 \mathrm{mmol}$ ) was added dropwise until the mixture remained colorless. The solvent was then immediately removed under vacuum and the oily residue triturated with pentane $(3 \times 5 \mathrm{~mL})$ to obtain an analytically pure white powder $\left(156 \mathrm{mg}, 75 \%\right.$ yield). Anal. Calcd. For [(CAAC) ${ }_{2} \mathrm{Zn}-$ $\mathrm{Me}]\left[\mathrm{B}\left(\mathrm{C}_{6} \mathrm{~F}_{5}\right)_{4}\right], \mathrm{C}_{65} \mathrm{H}_{65} \mathrm{BF}_{20} \mathrm{~N}_{2} \mathrm{Zn}: \mathrm{N}, 2.11 ; \mathrm{C}, 58.68 ; \mathrm{H}, 4.92$. Found: $\mathrm{N}$, 1.99; C, 58.35; H 4.57. ${ }^{1} \mathrm{H} \mathrm{NMR}\left(400 \mathrm{MHz}, \mathrm{CD}_{2} \mathrm{Cl}_{2}\right): \delta(\mathrm{ppm})-0.64$ (s, $3 \mathrm{H}$, $\mathrm{ZnMe}$ ), 1.07 (br, 12H, CMe $), 1.16(\mathrm{~d}, 12 \mathrm{H}, \mathrm{Pr}), 1.30(\mathrm{~d}, 12 \mathrm{H}, \mathrm{Pr}), 1.36$ (s, 12H, CMe $), 1.91$ (s, 4H, CH ${ }_{2}$ ), 2.76 (sept, 4H, $\mathrm{Pr}$ ), 7.35 (d, 2H, Ar), 7.47 (t, 4H, Ar); ${ }^{19} \mathrm{~F}$ NMR (282 MHz, $\left.\mathrm{CD}_{2} \mathrm{Cl}_{2}\right): \delta(\mathrm{ppm})-168.6(\mathrm{t}, 2 \mathrm{~F})$, $164.7(\mathrm{t}, 1 \mathrm{H}),-134.0(\mathrm{~d}, 2 \mathrm{~F})$.

[(CAAC)Zn- $\left.\mathbf{C}_{6} \mathbf{F}_{5}\right]\left[\mathbf{B}\left(\mathbf{C}_{6} \mathbf{F}_{5}\right)_{4}\right] \quad\left([\mathbf{7}]\left[\mathbf{B}\left(\mathbf{C}_{6} \mathbf{F}_{5}\right)_{4}\right]\right)$. To a $-35{ }^{\circ} \mathrm{C}$ solution of $\mathrm{ZnMe}_{2}(14.08 \mathrm{mg}, 175 \mu \mathrm{mol})$ in $\mathrm{C}_{6} \mathrm{H}_{5} \mathrm{~F}(1 \mathrm{~mL})$ is added dropwise a $-35^{\circ} \mathrm{C}$ solution of CAAC (50 mg, $175 \mu \mathrm{mol})$ in $\mathrm{C}_{6} \mathrm{H}_{5} \mathrm{~F}(1 \mathrm{~mL})$ giving a colorless solution that is immediately added drop wise to a room temperature dark orange $\mathrm{C}_{6} \mathrm{H}_{5} \mathrm{~F}$ solution of $\left[\mathrm{CPh}_{3}\right]\left[\mathrm{B}\left(\mathrm{C}_{6} \mathrm{~F}_{5}\right)_{4}\right](145.4 \mathrm{mg}, 158 \mu \mathrm{mol}$ in $1 \mathrm{~mL})$ until the mixture is colorless. The mixture is then added to a solution of $\mathrm{B}\left(\mathrm{C}_{6} \mathrm{~F}_{5}\right)_{3}(80.7 \mathrm{mg}, 175 \mu \mathrm{mol})$ in $\mathrm{C}_{6} \mathrm{H}_{5} \mathrm{~F}(1 \mathrm{~mL})$ and stirred for $24 \mathrm{~h}$. The solvent was removed under vacuum and the oily residue triturated with pentane $(5 \times 5 \mathrm{~mL})$ to obtain $\left[(\mathrm{CAAC}) \mathrm{Zn}-\mathrm{C}_{6} \mathrm{~F}_{5}\right]\left[\mathrm{B}\left(\mathrm{C}_{6} \mathrm{~F}_{5}\right)_{4}\right]$ as colorless crystals after recrystallization from $\mathrm{C}_{6} \mathrm{H}_{5} \mathrm{~F} /$ pentane $\left(95 \mathrm{mg}, 50 \%\right.$ yield). ${ }^{1} \mathrm{H}$ $\operatorname{NMR}\left(400 \mathrm{MHz}, \mathrm{C}_{6} \mathrm{D}_{5} \mathrm{Br}\right): \delta(\mathrm{ppm}) 7.27(\mathrm{t}, J=7.8 \mathrm{~Hz}, 1 \mathrm{H}, \mathrm{CH}-\mathrm{Ar}), 7.08$ (d, $J=7.8 \mathrm{~Hz}, 2 \mathrm{H}, \mathrm{CH}-\mathrm{Ar}$ ), 2.51 (hept, $J=6.7 \mathrm{~Hz}, 2 \mathrm{H}, \mathrm{CH}^{-}{ }^{-} \mathrm{Pr}$ ), 1.86 (s, $2 \mathrm{H}$, $\left.\mathrm{NC}(\mathrm{Me})_{2} \mathrm{CH}_{2} \mathrm{C}(\mathrm{Me})_{2} \mathrm{CN}\right), 1.28$ (s, $\left.6 \mathrm{H}, \mathrm{NC}(\mathrm{Me})_{2} \mathrm{CH}_{2} \mathrm{C}(\mathrm{Me})_{2} \mathrm{CN}\right), 1.14$ (d, $J$ $\left.=6.7 \mathrm{~Hz}, 6 \mathrm{H}, \mathrm{CH}_{3}{ }^{2} \mathrm{Pr}\right), 1.14\left(\mathrm{~s}, 6 \mathrm{~Hz}, \mathrm{NC}(\mathrm{Me})_{2} \mathrm{CH}_{2} \mathrm{C}(\mathrm{Me})_{2} \mathrm{CN}\right), 1.01(\mathrm{~d}, J=$ 
$\left.6.7 \mathrm{~Hz}, 6 \mathrm{H}, \mathrm{CH}_{3}{ }^{-} \mathrm{Pr}\right) .{ }^{19} \mathrm{~F} \mathrm{NMR}\left(282 \mathrm{MHz}, \mathrm{C}_{6} \mathrm{D}_{5} \mathrm{Br}\right) \delta(\mathrm{ppm})-117.85$, $118.11\left(\mathrm{~m}, o-\mathrm{ZnC}_{6} \mathrm{~F}_{5}\right),-132.52\left(\mathrm{bd}, o-\mathrm{B}\left(\mathrm{C}_{6} \mathrm{~F}_{5}\right)_{4}\right),-150.02\left(\mathrm{t}, J_{F F}=19.8 \mathrm{~Hz}\right.$, $\left.p-\mathrm{ZnC}_{6} \mathrm{~F}_{5}\right),-158.69,-159.93\left(\mathrm{~m}, m-\mathrm{ZnC}_{6} \mathrm{~F}_{5}\right),-162.97\left(\mathrm{t}, J_{F F}=21.0 \mathrm{~Hz}, p-\right.$ $\left.\mathrm{B}\left(\mathrm{C}_{6} \mathrm{~F}_{5}\right)_{4}\right),-166.81\left(\mathrm{bt}, \mathrm{m}-\mathrm{B}\left(\mathrm{C}_{6} \mathrm{~F}_{5}\right)_{4}\right) \cdot{ }^{13} \mathrm{C}$ NMR $\left(150 \mathrm{MHz}, \mathrm{C}_{6} \mathrm{D}_{5} \mathrm{Br}, 298 \mathrm{~K}\right)$ $\delta(\mathrm{ppm}) 229.36$ (carbene), $148.46\left(\mathrm{dm}, J_{C F}=242.4 \mathrm{~Hz}, o-\mathrm{C}_{6} \mathrm{~F}_{5}\right), 144.0$ (C-Ar), $138.31\left(\mathrm{dm}, J_{C F}=238.6 \mathrm{~Hz}, p-\mathrm{C}_{6} \mathrm{~F}_{5}\right), 136.38\left(\mathrm{dm}, J_{C F}=251.3 \mathrm{~Hz}\right.$, $\left.m-\mathrm{C}_{6} \mathrm{~F}_{5}\right), \quad 132.52\left(\mathrm{C}_{\text {ipso }}\right), \quad 129.84$ (CH-Ar), 123.86 (CH-Ar), 86.06 $\left(\mathrm{NC}(\mathrm{Me})_{2} \mathrm{CH}_{2} \mathrm{C}(\mathrm{Me})_{2} \mathrm{CN}\right), \quad 53.53 \quad\left(\mathrm{NC}(\mathrm{Me})_{2} \mathrm{CH}_{2} \mathrm{C}(\mathrm{Me})_{2} \mathrm{CN}\right), \quad 48.51$ ( $\left.\mathrm{NC}(\mathrm{Me})_{2} \mathrm{CH}_{2} \mathrm{C}(\mathrm{Me})_{2} \mathrm{CN}\right), 28.78\left(\mathrm{CH}-{ }^{-} \mathrm{Pr}\right), 28.22\left(\mathrm{NC}(\mathrm{Me})_{2} \mathrm{CH}_{2} \mathrm{C}(\mathrm{Me})_{2} \mathrm{CN}\right)$, $\left.27.35\left(\mathrm{NC}(\mathrm{Me})_{2} \mathrm{CH}_{2} \mathrm{C}(\mathrm{Me})_{2} \mathrm{CN}\right)\right), 26.73\left(\mathrm{CH}_{3}{ }^{-} \mathrm{Pr}\right), 22.48\left(\mathrm{CH}_{3}{ }^{-} \mathrm{Pr}\right)$. Anal Calcd. For $\mathrm{C}_{50} \mathrm{H}_{31} \mathrm{BF}_{25} \mathrm{NZn}$ : N, 1.17; C, 50.17; H 2.61. Found: $\mathrm{N}, 1.21$; $\mathrm{C}$, $50.26 ; \mathrm{H} 2.42$

\section{Acknowledgements ((optional))}

The CNRS and the University of Strasbourg are gratefully acknowledged for financial support. J.-C. B. thanks the French Ministry of Research and Higher Education for a PhD fellowship.

Keywords: zinc alkyls • cation • Lewis acid • CAAC carbene • hydrosilylation

[1] a) S. P. Nolan in N-Heterocyclic Carbenes: Effective Tools in Organometallic Synthesis (Eds.: S. P. Nolan), Wiley-VCH, Weinheim 2014; b) D. Bourissou, O. Guerret, F. Gabbaï, G. Bertrand, Chem. Rev. 2008, 1, 39; c) W. A. Herrmann, Angew. Chem. Int. Ed. 2002, 41, 1290 Angew. Chem. 2002, 114, 1342; d) V. César, S. Bellemin-Laponnaz, L. H. Gade, Chem. Soc. Rev. 2004, 33, 619; e) P. de Frémont, N. Marion, S. P. Nolan, Coord. Chem. Rev. 2009, 253, 862; f) C. Fliedel, G. Schnee, T. Avilés, S. Dagorne, Coord. Chem. Rev. 2014, 275, 63; g) S. Bellemin-Laponnaz, S. Dagorne, Chem. Rev. 2014, 114, 8747; g) H. V. Huynh, Chemical Reviews 2018, 118 (19), 9457; h) Peris, E. Smart Chemical Reviews 2018, 118 (19), 9988.

[2] a) V. Nesterov, D. Reiter, P. Bag, P. Frisch, R. Holzner, A. Porzelt, S. Inoue, Chem. Rev. 2018, 118 (19), 9678; b) J. Cheng, L. Wang, P. Wang, L. Deng, Chem. Rev. 2018, 118 (19), 9930; c) H. W. Roesky, J. Organomet. Chem. 2013 730, 57.

[3] a) V. Lavallo, Y. Canac, A. DeHope, B. Donnadieu, G. Bertrand, Angew. Chem. Int. Ed. 2005, 44, 7236; Angew. Chem. 2005, 117, 7402; b) M. Melaimi, R. Jazzar, M. Soleilhavoup, G. Bertrand, Angew. Chem. Int Ed. 2017, 56, 10046; Angew. Chem. 2017, 129, 10180.

[4] a) S. Roy, K. C. Mondal, H. W. Roesky, Acc. Chem. Res. 2016, 49 (3), 357.

[5] a) X. Zeng, G. D. Frey, R. Kinjo, B. Donnadieu, G. Bertrand, J. Am. Chem. Soc. 2009, 131, 8690; b) X. Zeng, R. Kinjo, B. Donnadieu, G. Bertrand, Angew. Chem. Int. Ed. 2010, 49, 942; Angew. Chem. 2010, 122, 954; c) B. Rao, H. Tang, X. Zeng, L. Liu, M. Melaimi, G. Bertrand, Angew. Chem. Int. Ed. 2015, 54, 14915; Angew. Chem. 2015, 127, 15128; d) U. S. D. Paul, U. Radius, Organometallics 2017, 36, 1398; e) U. S. D. Paul, U. Radius, Eur. J. Inorg. Chem. 2017, 2017, 3362.

[6] R. Kinjo, B. Donnadieu, M. A. Celik, G. Frenking, G. Bertrand, Science 2011, 333, 610.

[7] a) S. Kundu, P. P. Samuel, S. Sinhababu, A. V. Luebben, B. Dittrich, D. M. Andrada, G. Frenking, A. C. Stückl, B. Schwederski, A. Paretzki, W Kaim, H. W. Roesky J. Am. Chem. Soc. 2017, 139, 11028; b) S. Kundu, S. Sinhababu, S. Dutta, T. Mondal, D. Koley, B. Dittrich, B. Schwederski, W. Kaim, A. C. Stückl, H. W. Roesky, Chem. Comm 2017, 53, 10516; c) Y. Li, Y.-C. Chan, B.-X. Leong, Y. Li, E. Richards, I. Purushothaman, S. De, P. Parameswaran, C.-W. So, Angew. Chem. Int. Ed. 2017, 56, 7573; Angew. Chem. 2017, 129, 7681
[8] O. Back, G. Kuchenbeiser, B. Donnadieu, G. Bertrand, Angew. Chem. Int. Ed. 2009, 48, 5530; Angew. Chem. 2009, 121, 5638

[9] a) G. D. Frey, J. D. Masuda, B. Donnadieu, G. Bertrand, Angew. Chem. Int. Ed. 2010, 49, 9444; Angew. Chem. 2010, 122, 9634; b) A. F. Eichhorn, L. Kuehn, T. B. Marder, U. Radius, Chem. Commun. 2017, 53, 11694; c) H. Schneider, A. Hock, R. Bertermann, U. Radius, Chem. Eur. J. 2017, 23, 12387.

[10] R. Kinjo, B. Donnadieu, G. Bertrand, Angew. Chem. Int. Ed. 2011, 50 5560; Angew. Chem. 2011, 123, 5674.

[11] Y. Wei, B. Rao, X. Cong, X. Zeng, J. Am. Chem. Soc. 2015, 137, 9250.

[12] a) S. Dagorne, Synthesis 2018, 50, 3662; b) S. Budagumpi, S. Endud, Organometallics 2013, 32, 1537.

[13] a) P. Jochmann, D. W. Stephan, Chem. Eur. J. 2014, 20, 8370; b) O Jacquet, X. Frogneux, C. Das Neves Gomes, T. Cantat, Chem. Sci. 2013, 4, 2127; c) C. Fliedel, D. Vila-Viçosa, M. J. Calhorda, S. Dagorne, T. Avilés, ChemCatChem. 2014, 6, 1357; d) Y. Lee, B. Li, A. H. Hoveyda, J. Am. Chem. Soc. 2009, 131, 11625; e) T. R. Jensen, L. E. Breyfogle, M. A. Hillmyer, W. B. Tolman, Chem. Commun. 2004, 2504; f) G. Schnee, C. Fliedel, T. Avilés and S. Dagorne, Eur. J. Inorg. Chem. 2013, 3699.

[14] a) D. Specklin, C. Fliedel, C. Gourlaouen, J.-C. Bruyere, T. Avilés, C. Boudon, L. Ruhlmann, S. Dagorne, Chem. Eur. J. 2017, 23, 5509; b) D. Specklin, F. Hild, C. Fliedel, C. Gourlaouen, L. F. Veiros, S. Dagorne Chem. Eur. J. 2017, 23, 15908.

[15] For a comprehensive review on $\mathrm{Zn}(\mathrm{II})$ organocations, see: $\mathrm{M}$. Bochmann, Coord. Chem. Rev. 2009, 253, 2000.

[16] T. Hirose, K. Kodama, in Comprehensive Organic Synthesis, $2^{\text {nd }}$ edition (eds.: P. Knochel, G. A. Molander, Elsevier B. V.) Amsterdam, 2014, Vol. 1, pp 204-266.

[17] A. P. Singh, P. P. Samuel, H. W. Roesky, M. C. Schwarzer, G. Frenking, N. S. Sidhu, B. A. Dittrich, J. Am. Chem. Soc. 2013, 135 7324.

[18] A. Khan, W. Jadwisienczak, M. E. Kordesch, Physica E 2006, 33, 331.

[19] L. R. Collins, G. Hierlmeier, M. F. Mahon, I. M. Riddlestone, M. K. Whittlesey, Chem. Eur. J. 2015, 21, 3215

[20] D. Tapu, D. A. Dixon, C. Roe, Chem. Rev. 2009, 109, 3385.

[21] For the method used for volume estimation of $[7]\left[B\left(C_{6} F_{5}\right)_{4}\right]$ in solution, see: a) L. Allouche, A. Marqui, J.-M. Lehn, Chem. Eur. J. 2006, 12 7520; b) N. Giuseppone, J.-L Schmitt, L. Allouche, J.-M Lehn, Angew. Chem. Int. Ed. 2008, 47, 2235; Angew. Chem. 2008, 120, 2267.

[22] H. Böhrer, N. Trapp, D. Himmel, M. Schleep, I. Krossing, Dalton Trans. 2015, 44, 7489

[23] H. Großekappenberg, M. Reißmann, M. Schmidtmann, T. Müller Organometallics 2015, 34, 4952.

[24] For a recent review on strong Lewis acids and their classification, see: L. Greb, Chem. Eur. J. 2018, 24, 17881.

[25] V. Gutmann, Coord. Chem. Rev. 1976, 18, 225; b) M. A. Beckett, D. S. Brassington, M. E. Light, M. B. Hursthouse, J. Chem. Soc. Dalton Trans. 2001, 1768 .

[26] A. R. Nödling, K. Müther, V. H. G. Rohde, G. Hilt, M. Oestreich Organometallics 2014, 33, 302

[27] a) K. O. Christe, D. A. Dixon, D. McLemore, W. W. Wilson, J. A Sheehy,J. A. Boatz, J. Fluorine Chem. 2000, 101, 151; b) L. O. Meller D. Himmel, J. Stauffer, G. Steinfeld, J. Slattery, G. Santiso-QuiÇones V. Brecht, I. Krossing, Angew. Chem. Int. Ed. 2008, 47, 7659; Angew. Chem. 2008, 120, 7772

[28] Recent review on hydrosilylation catalysis by boranes: M. Oestreich, J.Hermeke, J. Mohr, Chem. Soc. Rev. 2015, 44, 2202.

[29] For a recent review on metal-mediated $\mathrm{CO}_{2}$ hydrosilylation catalysis, see: F. J. Fernández- Alvarez, L. A. Oro, ChemCatChem 2018, 10 4783.

[30] a) W. Sattler, G. Parkin, J. Am. Chem. Soc. 2011, 133, 9708. b) W. Sattler, G. Parkin, J. Am. Chem. Soc. 2012, 134, 17462; c) M. Khandelwal, R. J. Wehmschulte, Angew. Chem. Int. Ed. 2012, 51, 7323; Angew. Chem. 2012, 124, 7435; d) A. Rit, A. Zanardi, T. P. 
Spaniol, L. Maron, J. Okuda, Angew. Chem. Int. Ed. 2014, 53, 13273 ; Angew. Chem. 2014, 126, 13489; e) M. Rauch, G. Parkin, J. Am. Chem. Soc. 2017, 139, 18162; f) M. Tüchler, L. Gärtner, S. Fischer, A. D. Boese, F. Belaj, N. C. Mösch-Zanetti, Angew. Chem. Int. Ed. 2018, 57, 6906; Angew. Chem. 2018, 130, 7022.
[31] J. Chen, L. Falivene, L. Caporaso, L. Cavallo, E. Y.-X. Chen, J. Am. Chem. Soc. 2016, 138, 5321. 
Entry for the Table of Contents (Please choose one layout)

Layout 1:

\section{FULL PAPER}

Text for Table of Contents

Layout 2:

\section{FULL PAPER}

((Insert TOC Graphic here: max. width: $5.5 \mathrm{~cm}$; max. height: $5.0 \mathrm{~cm}$ ))
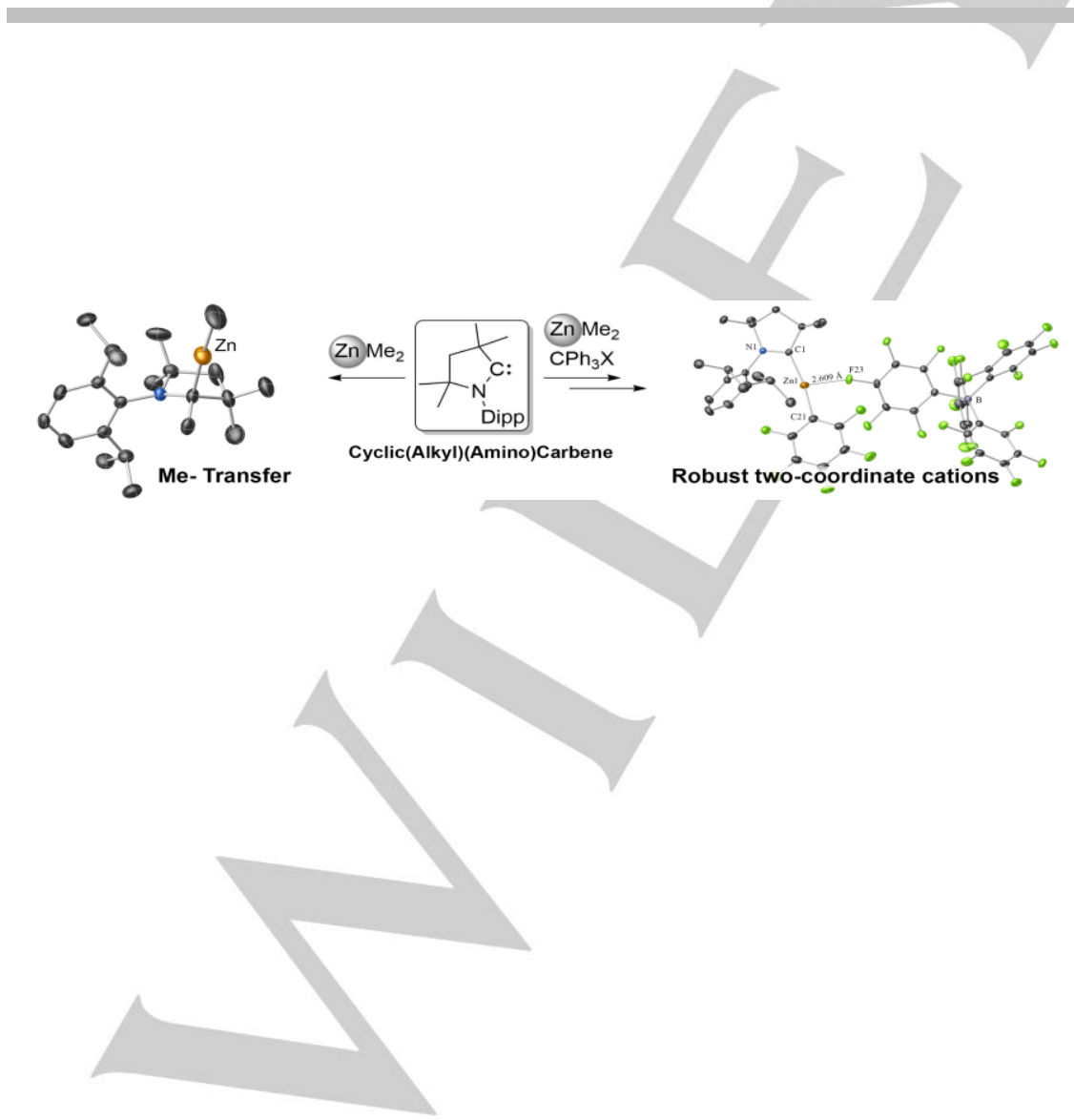

Author(s), Corresponding Author(s)*

Page No. - Page No.

Title

Author(s), Corresponding Author(s)*

Page No. - Page No.

Title 